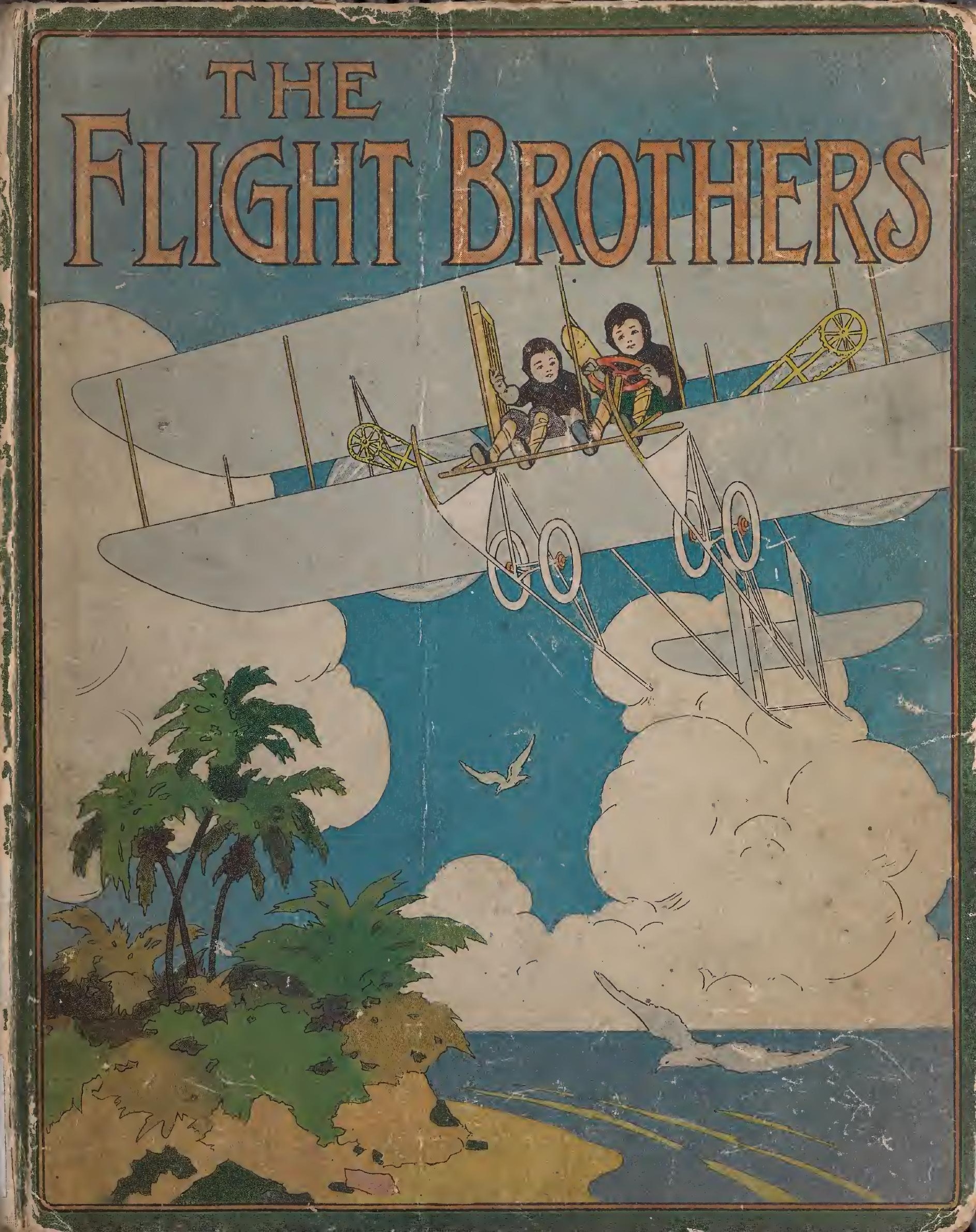




$$
12^{5}
$$





\section{THE FLIGHT BROTHERS}



$+$

.

, 


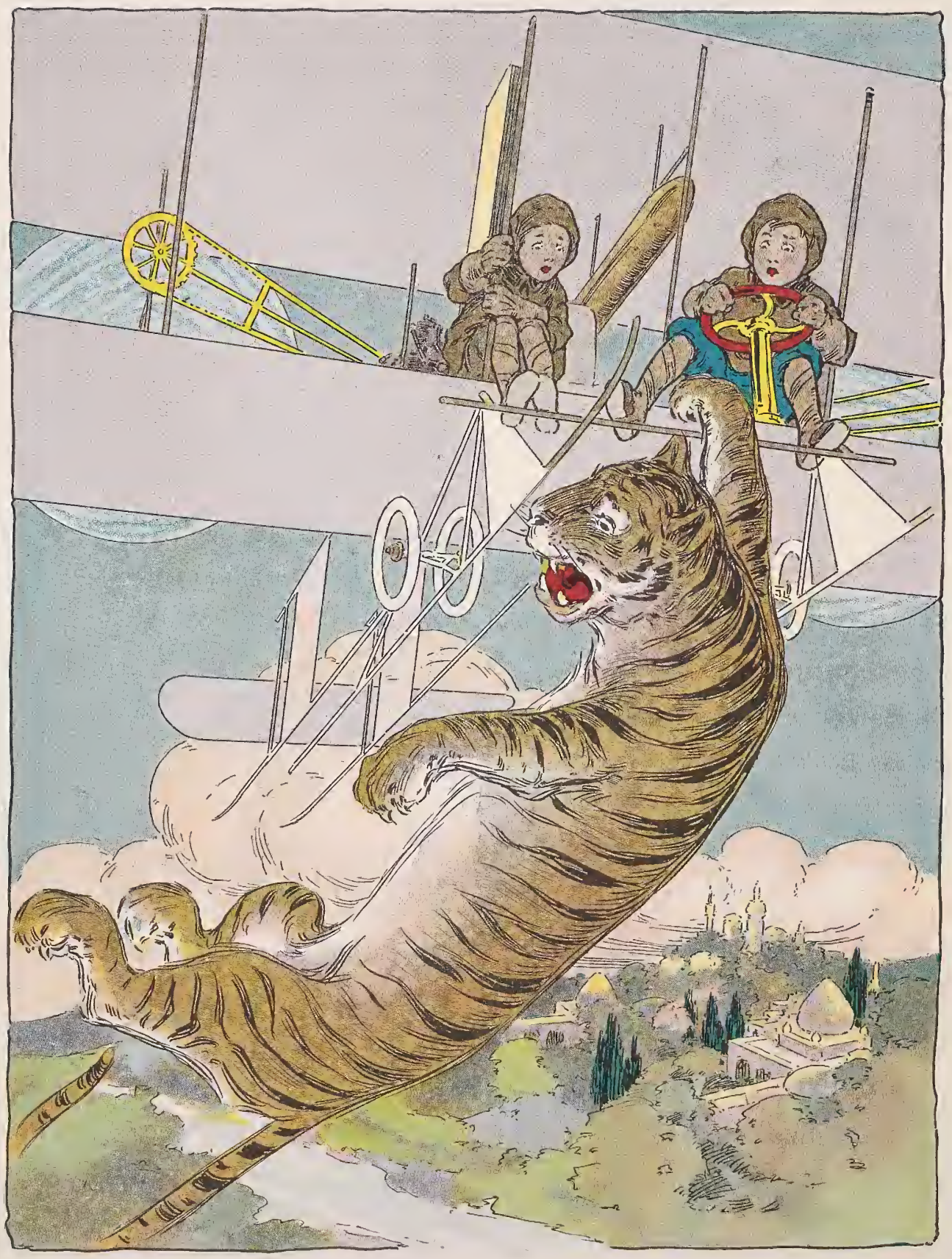


Copyright, 1912

By

The Reilly \& Britton Company

The Flight Brothers 
This book is dedicated

to the two great inventors and aviators but for whom there would have been no Flight Brothers 



\section{Contents}

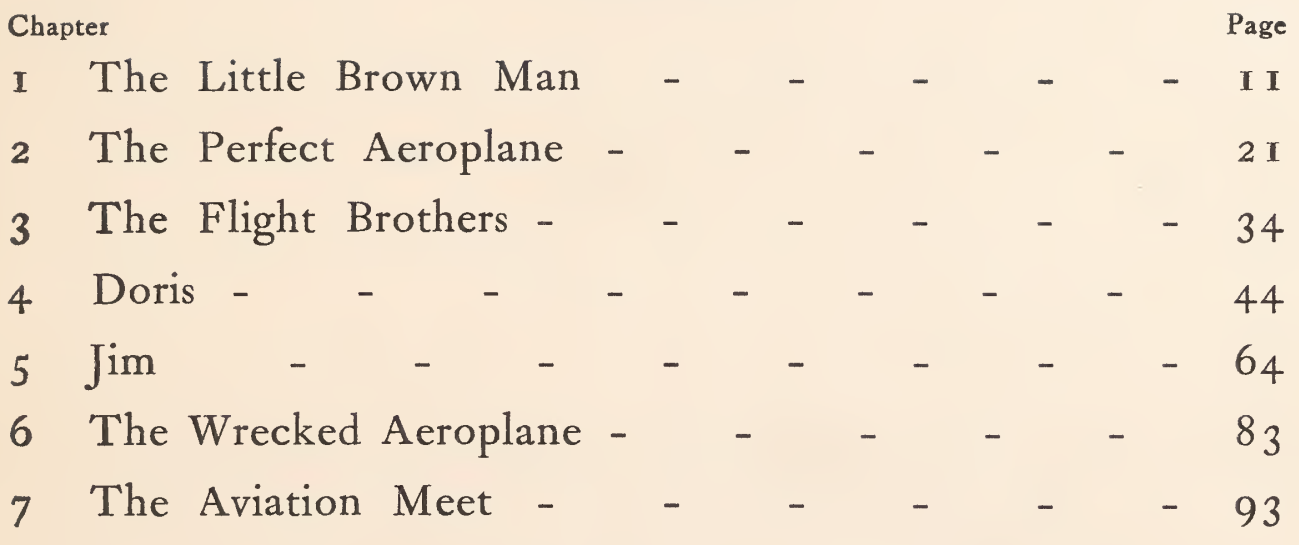





\section{List of Illustrations}

For an instant the tiger clung uncertainly Frontispiece "My, that's queer," said Billy - _ _ _ _ - $\quad$ I 3 He glided through the air like a bird - _ - 17 The return of the Little Brown Man - _ - 23 "Jump in, Jack, and do as I have done" - - 26 "You're just splendid," said the boy - _ _ - - 33 "What's that?" cried Jack, rising with a start - - 38 "Who is that?" she asked sharply - - - - 40 "That looks mighty good," said Jack - _ - 47 "Give me your hand and we'll run for our lives!" - $5^{2}$ A burly Englishman grasped him by the shoulder - $6 \mathrm{I}$ The aeroplane dived and plunged like a kite - - 69 The boys became frightened and started to run - 72 The boys were the undisputed heroes of the town - $8 \mathrm{I}$ "I wouldn't take a chance on them," said Jack - 85 Jack commanded the man to let go - - - 92 The Aviation Meet - $\quad$ - $\quad$ - $\quad$ - $\quad$ - $\quad$ - 95 The record of the trip - $\quad$ - $\quad$ - $\quad$ - $\quad$ - 99 



\section{The Flight Brothers}

CHAPTER I

\section{The Little Brown Man}

Jack and Billy Jones had the most extraordinary adventure for two such small boys; Jack was only twelve and Billy ten. It all began on a warm summer day after school had closed and the boys were spending their vacation in the country. On this particular day the wind was just right and Jack was flying an immense new box kite, while Billy sat beside him making another of similar construction.

"Billy," said Jack wistfully, "don't you wish our kite was a biplane and we were up there flying?" "Say, you bet," answered Billy with enthusiasm. "Then we would be called aviators and be quite celebrated, wouldn't we?"

"Yep!" 


\section{The Flight Brothers}

There was silence for a few minutes, when Jack exclaimed:

"Say, look at that strange bird!"

Billy looked up and saw what appeared to be a large bird circling uncertainly around the kite. Suddenly it swooped upon the kite and seemed to cling to it while it flapped one wing and was evidently in great distress.

"My, that's queer," said Billy. "Pull her in, Jack!"

The kite wobbled and dived, while both boys pulled in as fast as they could, without winding the string.

"The bird's still holding on," cried Billy. "It must be a hawk or maybe an eagle."

"What's that?" said Jack as something fell from the bird.

"Looks as though he might be losing a wing," replied Billy. "That's a funny bird; he must be coming apart.”

But soon the kite gave a despairing dive and fell to the earth directly behind a hedge of lilac bushes.

In great excitement the boys ran toward it and 


\section{The Flight Brothers}

drawing near, heard noises that sounded like a human being.

They stopped and listened with very queer expressions on their faces. Jack looked at Billy and Billy looked at Jack.

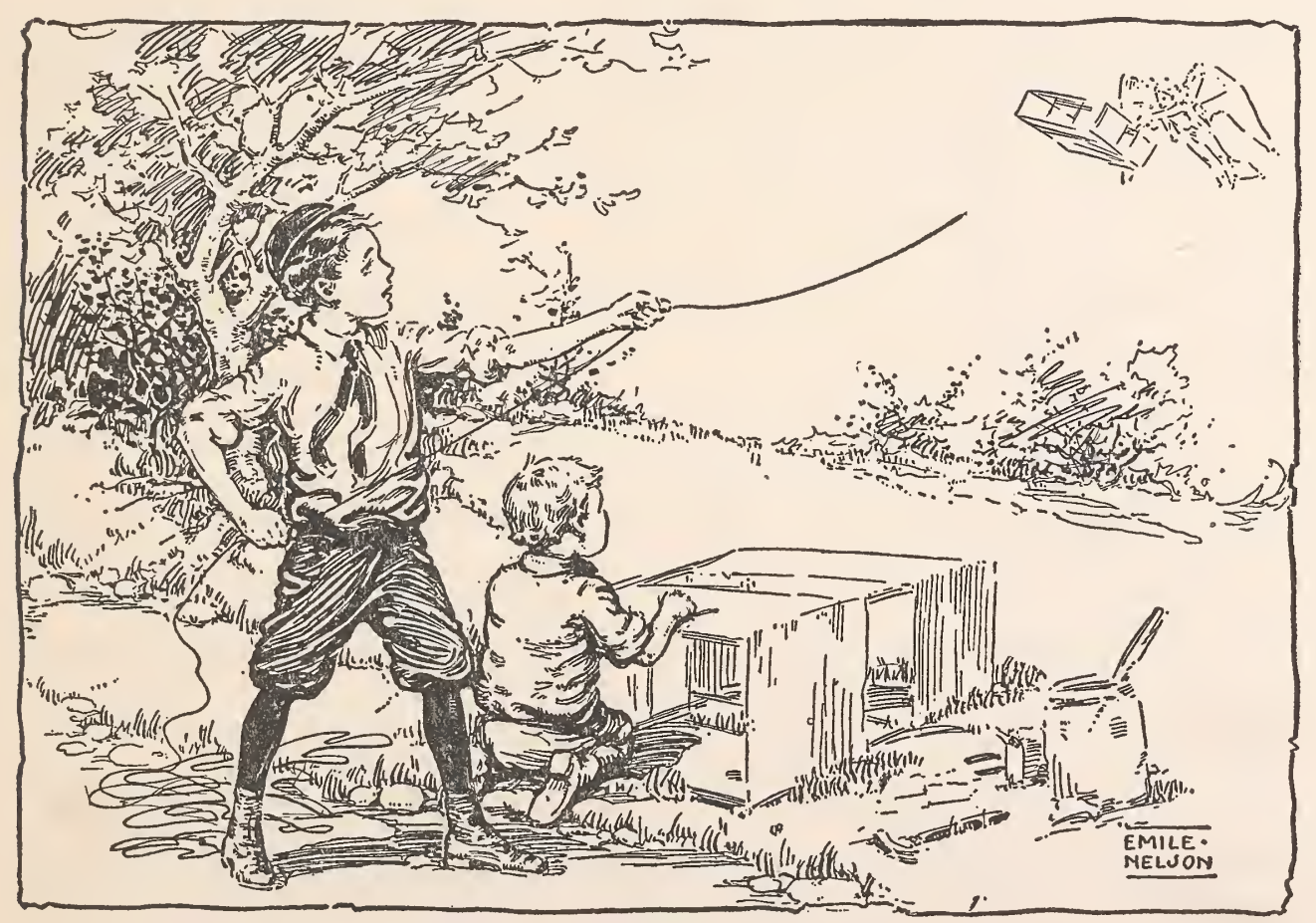

"Are you game to go through the bushes?" inquired Billy as he glanced doubtfully at his brother. "If I were sure that bird—- began Jack but was 


\section{The Flight Brothers}

interrupted by an agonized voice crying: "Oh, my wing, my wing!"

"Wow!" whispered Billy. "Me for home. I don't want to get mixed up with a bird wise enough to talk. "Oh, my wing, my wing," the voice wailed sorrowfully.

"The poor thing is hurt," said Jack. "I am going to see him; besides, a bird that can talk is too good to miss. Aw, come on, Billy!"

"All right," replied the boy and they both pushed through the bushes.

To hear a bird talk is surprise enough for anyone, but the sight that met their eyes gave them quite another shock. On the ground beside the kite sat a little man with a long white beard. He wore a brown suit, and fastened to his back was one strange mechanical-looking wing; on his feet, instead of shoes, were queerly shaped things about three feet long; these resembled the fins of a fish.

"I fear I have damaged your kite," he said regarding the boys with two little sharp black eyes.

"Oh, that's all right," Jack assured. "We're 


\section{The Flight Brothers}

making another one anyway. Did you hurt yourself?" "No, not at all," answered the little man. "But I would have been killed if your kite had not been just where it was in the sky. In a needless hurry this morning I did not securely fasten my left wing and now I have lost it. I am sure I do not know what to do, for I have never before had an accident."

"I saw your wing drop," said Jack. "I'll go and see if I can find it." And away he ran.

"I am Billy Jones and that's my brother, Jack Jones," volunteered Billy. "What's your name?"

"You may call me the Little Brown Man," he answered evasively. "I am an inventor, but not a famous one; nor do I wish to be. You two boys are the only ones, besides my old and trusted servant, who ever saw anything I invented."

"How is that?" asked Billy.

"Well, you see, I am a dwarf," replied the Little Brown Man sadly, "and I have a very sensitive disposition. If I were to give my inventions to the world at this time, at first they would be scoffed at; then some would try to steal them even if I had them patented 


\section{The Flight Brothers}

and I would have to fight continually for my rights. Then there are the newspaper men with whom I would be pestered; perhaps they would even cartoon meugh! I couldn't stand it, and as it is, I am very happy and contented in my work. Of course I do not mean to deprive the world of any of my inventions, and have made plans and models of them so that when I die these can be used."

Just then Jack came crashing through the bushes, holding high above his head the lost wing.

"I found it! I found it!" he shouted triumphantly. “Thank you very much, my boy," said the Little Brown Man gratefully as he took it and fastened it onto his back.

After it was securely fastened he pressed a small button on the front of his coat; a soft purring sound was heard. Then, flapping his wings bird-fashion he flew directly upward; with heels together and toes pointed like a dancer's, his odd-looking footgear formed itself into an exact imitation of a bird's tail.

The boys, wondering, watched him as he glided through the air with the ease and grace of a bird; in 


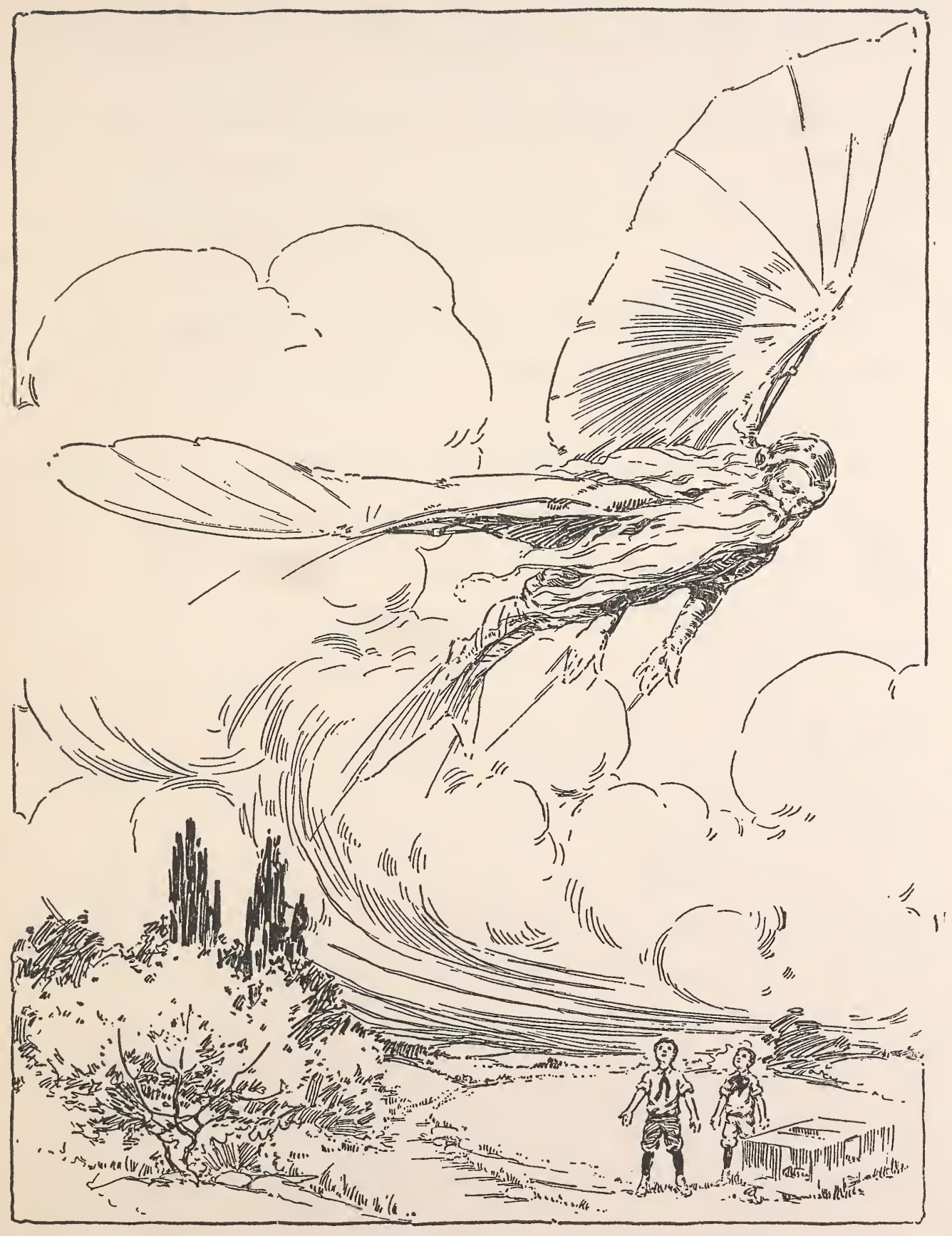




\section{The Flight Brothers}

fact, from a short distance it was impossible to tell the difference.

In a few minutes he returned to the boys, smiling happily.

"My wing is not injured at all," he said. "I was afraid the fall might damage it on account of the delicate construction."

"That's some invention," cried Billy admiringly.

"Yes," said the little man, although he didn't quite understand Billy's slang.

"It's certainly great!" exclaimed Jack.

"I think my aeroplane is even better," said the little inventor reflectively.

"Aeroplane!" fairly shouted the boys. "Did you make an aeroplane?"

"Yes, indeed," was the reply. "That is what I travel in. I live in a country away across the Atlantic Ocean. I never use my aeroplane except at night; during the day I hide it in some lonely place and use my wings. Also, I often take a suit case and fly on my wings to a secluded spot near a city, and then, packing the whole outfit into the suit case, enter the 


\section{The Flight Brothers}

city and mingle with the people unnoticed; they look upon me as just a little old man."

"You're a wonder," said Jack, then asked, "What kind of an aeroplane is yours?"

"A biplane," replied the little man proudly; "and there is not a plane in existence that can equal it."

"Oh, I've seen lots of aeroplanes," said Jack in a careless way. "That's not as wonderful as your bird outfit. I never saw one of those before."

"My dear boy," ejaculated the Little Brown Man impatiently, "of course you have not, but I insist that my aeroplane is a still greater achievement. I have been all over the world and examined every type of aeroplane that has ever been constructed, and my biplane is the only one absolutely safe. Any boy could manipulate it without fear of accident."

Jack and Billy drew in their breath in a longdrawn-out whistle. This was hardly possible, they thought.

"Aw, come," said Billy; "you're stringin' us."

"You do not believe," said the Little Brown Man irritably. "Very well. It is just such distrust-but 


\section{The Flight Brothers}

no matter. I will fly away now; but before going I should like to know how I can reward you for your kindness to me. You may wish for anything in the world and I will bring it to you."

"For anything?" asked Billy incredulously.

"Certainly," was the answer.

"I don't know what to wish for," said Jack.

"A pony," suggested Billy; "or a gun or-"

"I know-I know!" cried Jack suddenly. "Say, Little Brown Man, I'd rather have a ride in your aeroplane than anything else in the world."

"Fine," agreed Billy fervently. "We were just wishing before you came that we were aviators."

"Well, well," said the small inventor, evidently very much pleased. "That being the case, I shall have an extraordinary treat for you, the nature of which I will not disclose to you now; but to-morrow morning at about this same time I will return to you here. But one condition I impose: tell no one about it, as I do not propose to be annoyed with people."

While the boys voiced their ready promise the Little Brown Man spread his wings and flew away. 


\section{CHAP'TER II}

\section{The Perfect Aeroplane}

Immediately after their breakfast on the following morning, Jack and Billy went out behind the lilac hedge and waited for three hours before they saw the Little Brown Man coming towards them from out of the blue sky on his mechanical wings.

"Wonder where his biplane is," said Jack.

"Perhaps he was only fooling us," suggested Billy. "No," answered Jack decidedly, "he's not that kind. I'm willing to believe anything he says,"

"Well, if you are, so'm I, Jack."

When the little inventor landed, the first thing he said was:

"Have you told anyone?"

"Not a soul," was the reply. 


\section{The Flight Brothers}

"Good!" he cried. "You wished for a ride in my biplane. I am going to do even better than that for you. I will allow you to take a trip around the world in it. Would you like to?"

"Would a duck swim?" gurgled Billy, trying to stand on his head from pure joy.

"What!" exclaimed Jack. "You can't mean it, Little Brown Man."

"Indeed I do," he replied. "I want to go to the city for a couple of weeks and in that time you can easily circle the earth in my swift little biplane."

Jack looked disappointed.

"We can't run an aeroplane," he said. "We don't know how. Won't you take us up in it yourself?"

"Tush, tush," cried the little man impatiently. "You do make me most tired. It is not difficult to operate. I can show you how in five minutes."

"Nix," said Billy. "That sounds easy, but I don't want my neck broken."

"Silly fool!" hissed the small inventor, now thoroughly angry. "Did I not tell you it was perfectly safe? Would I say so if it were not?" he demanded. 


\section{The Flight Brothers}

"I dunno," answered Billy with a shrug.

"Say, look here, Billy," said Jack in disgust. "Just cut out that rudeness. I'm not afraid to trust him."

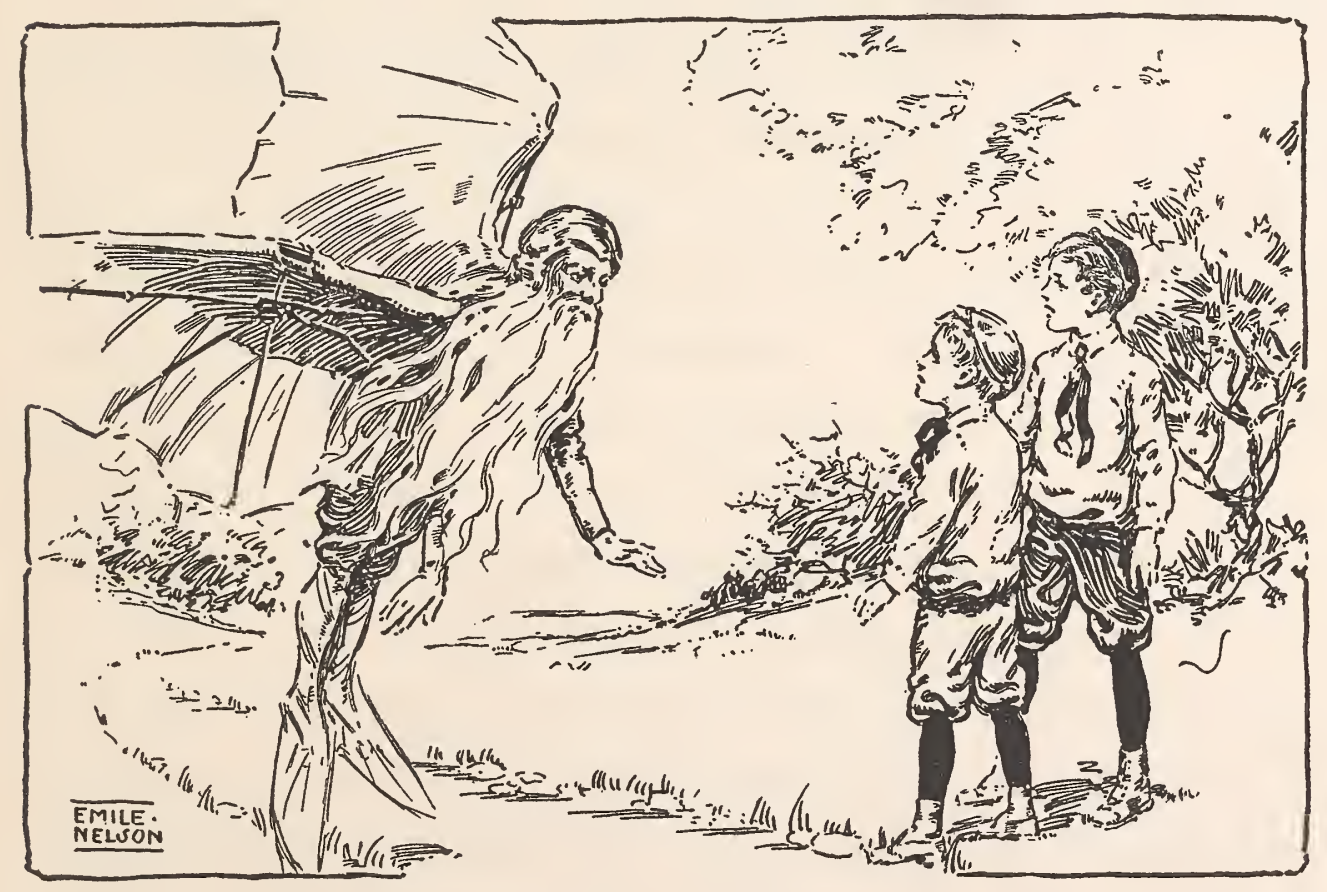

"Of course," said the Little Brown Man with great dignity, "if you do not care to use the aeroplane it does not matter to me; it was for your pleasure I offered it." 


\section{The Flight Brothers}

"And I say you're a brick," cried Jack warmly. "It's mighty nice of you. If you can show me how to run the thing, why, I'm game all right, and," turning to glance loftily at his younger brother, "if Billy's afraid, he needn't come."

"Who's afraid?" ejaculated Billy indignantly. "I'm not; but, gee whiz, it's all so blamed hard to believe."

"Yes, yes," agreed the little man contritely, "I suppose it is hard to believe in my wonderful inventions without even seeing them. But come, I will show you! Then you will of a certainty be convinced."

After removing his bird outfit, which would have been difficult to walk in, he tucked it all under one arm and then led them into a large cornfield near by. In the middle of this stood the aeroplane, entirely hidden by a grass-green silk cover; removing it, the little man displayed to the admiring gaze of the two boys the simplest and daintiest little flying machine they had ever seen. It stood on its four wheels with the runners behind, and appeared to be of exquisitely fragile construction; it seemed impossible that 


\section{The Flight Brothers}

this delicate looking affair could lift even its own motor. The whole thing was of one indescribable color: neither a blue nor yet a gray, although faintly suggesting both.

"See!" said the Little Brown Man, resting his hand lovingly on a wing tip. "This is the Perfect Aeroplane. It is just the color of atmosphere. Is it not beautiful?" he asked proudly.

"It's wonderful," breathed Jack softly, "and the most beautiful I have ever seen."

Billy only grunted, for it looked very unsubstantial to him.

"Now," cried the Little Brown Man, jumping in, "see how easy it is. This lever and wheel combined regulate the entire machine. You push it forward to go down-this way; backward to go up-like this; and straight up and down to sail on the level. Now this wheel controls the rudder; turn it this way to go to the right, and this way to go to the left. Come closer, boys! You see this small controller in the center of the wheel? Well, that is all that is required to operate the motor. See-I give it a slight push." 


\section{The Flight Brothers}

The propeller commenced to revolve.

"Now, look," he continued, "I push it furtherout of the way, boys, for up she goes. The more I turn the controller the faster she flies-" and then they heard his voice no more, for it was lost to them in the skies.

"That looks mighty easy," remarked Billy as he watched the flight of the Perfect Aeroplane, which being, as the little man said, the color of atmosphere, was rather difficult to see from any distance.

After circling about in the sky and exhibiting the biplane from all angles, the small inventor returned to find two profoundly impressed boys.

"You believe now?" he asked Billy.

"You betcha," replied the boy convincingly,

"Come!" commanded the Little Brown Man, alighting from the biplane. "Jump in, Jack, and do as I have done."

Jack hesitated.

"I say," he said; "supposing I do something wrong and the thing loses its balance and tips over?"

"Impossible!" was the answer. "The wing tips 


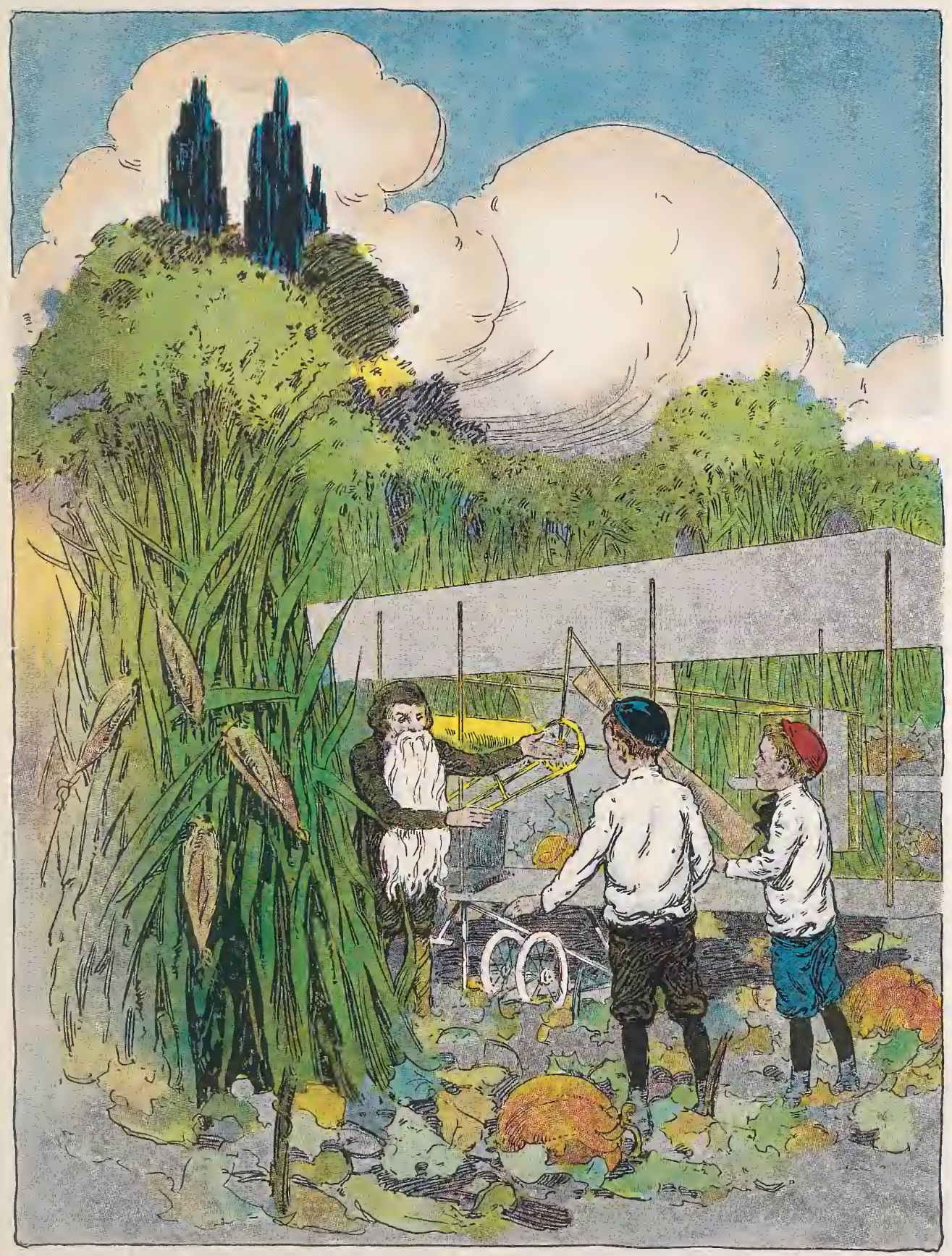





\section{The Flight Brothers}

adjust themselves automatically to prevent any such catastrophe."

“'Then I'll try it," said Jack bravely and took his place at the wheel.

First he pulled the lever towards him, then pushed the controller just as the Little Brown Man had done. Then he arose easily in the air and his heart throbbed to think that he, Jack Jones, aged only twelve, was operating with perfect confidence an aeroplane which the aviators whose flights he had witnessed and had been so envious of, would gladly give their fortunes to possess.

After reaching a height of about two hundred feet he pushed the lever so that it stood straight up and down, and for a few hundred yards sailed on a level, afterwards steering the machine back in the direction whence he came and finally making an easy landing, to the consternation and envy of Billy.

"That was worth a million dollars," cried Jack enthusiastically as he jumped to the ground.

"Well, are you ready for your trip?" asked the Little Brown Man, with a smile. 


\section{The Flight Brothers}

The boys looked at each other.

"We can't say anything to Anna-she wouldn't let us go," said Billy.

As it happened, Mr. and Mrs. Jones had gone on a motor trip the week before, intending to return in three weeks, and had left their boys in charge of an old servant named Anna.

"She'll worry," said Jack.

"Let her-she's a cross old thing," returned Billy hard-heartedly.

Now the Little Brown Man was so taken up with his own inventions that it probably never entered his head that these two boys had a mother and father who, if they knew of the proposed trip, would certainly not allow it.

Jack had no intention of breaking faith with the little inventor, but at the same time he did not like to leave without a word to anyone. So assuring Billy and the Little Brown Man that he would return in a few minutes he ran back to the house. When he reached there he took from his pocket a pencil and an old envelope and wrote on it: 


\section{The Flight Brothers}

"AnNa:

Don't worry. We are going away but will be back in two weeks sure.

JACK and BILLY."

This he fastened to the kitchen door where Anna would be sure to find it. $\mathrm{He}$ then returned as fast as he could to his brother and their new-found friend.

"You have nothing to fear," the Little Brown Man was explaining to Billy, "for there is not a thing to get out of order; no repairs will be needed, and the motor requires absolutely no attention. Are you ready?"

"You betcha," cried Billy joyfully. "On your marks - get set-"

"Yes," gasped Jack all out of breath but with a feeling that he had done his duty.

"Very well," said the little inventor. "Now it will be necessary for you to come in contact with people, but keep away from the civilized world as much as possible and be sure never to mention me to anyone. It would be well for you to travel under assumed names; you are bound to cause comment, 


\section{The Flight Brothers}

although if possible I would rather, as I said before, that you keep away from civilized people. They are sure to try to steal your aeroplane or cause trouble for you in some way."

"All right, we'll be careful," said the boys, who were so anxious to fly they would have promised anything.

"Let me see now," said the inventor with his finger placed thoughtfully on his forehead. "What can you call yourselves?"

Suddenly he chuckled to himself.

"That is good! ha-ha-ha!" he laughed with a mischievous twinkle in his eye. "I have it! Now listen to me! You must call yourselves the Flight Brothers. Jack, you are to be Wingbird Flight, and you, Billy, are to be Soarwell Flight. Now, remember -instead of Jack and Billy Jones-you are Wingbird and Soarwell Flight, the aviators. And the Perfect Aeroplane is your own machine for the next two weeks." "Bully!" cried the boys delightedly.

Then he showed them a light chest on board the aeroplane, from which he took a small suit case. 


\section{The Flight Brothers}

"I shall need this for myself," he explained. "Now in this chest you will find some food and water. This, also, is where I keep the cover for the aeroplane. Notice- it is grass-green on one side and dust color on the other. If you land on a grassy ground, throw the green side out; if on a sandy soil, throw the dust color out. This renders the whole thing inconspicuous. Also, in the chest you will find a box of money which you may require; and there is a couple of leather coats and caps. Put them on, for it is much cooler in the skies than on the earth. And here is a compass which you, Billy-I mean Soarwell—can wear on your wrist. Now I think the Flight Brothers are ready for their journey in the Perfect Aeroplane."

After they had put on the leather coats and caps, Jack went gravely up to the Little Brown Man and wrung his hand.

"You're just splendid," said the boy. "Thanks." "Tush, tush," remonstrated the little inventor. "It is indeed a pleasure to see you so appreciative." "Say," said Billy, "I've been a chump. But I know better now, and I'm sorry." 


\section{The Flight Brothers}

"That is all right, my boy, and I can hardly blame you," replied the little fellow. "Jump in now and start her off - that's right! Remember to be back here in two weeks."

"We will," cried the boys, climbing in.

Jack settled himself at the wheel and confidently started the motor.

As they sailed away he thought he heard the Little Brown Man laugh and say:

"The Flight Brothers-Wingbird and Soarwell Flight-ha! ha! ha!” 


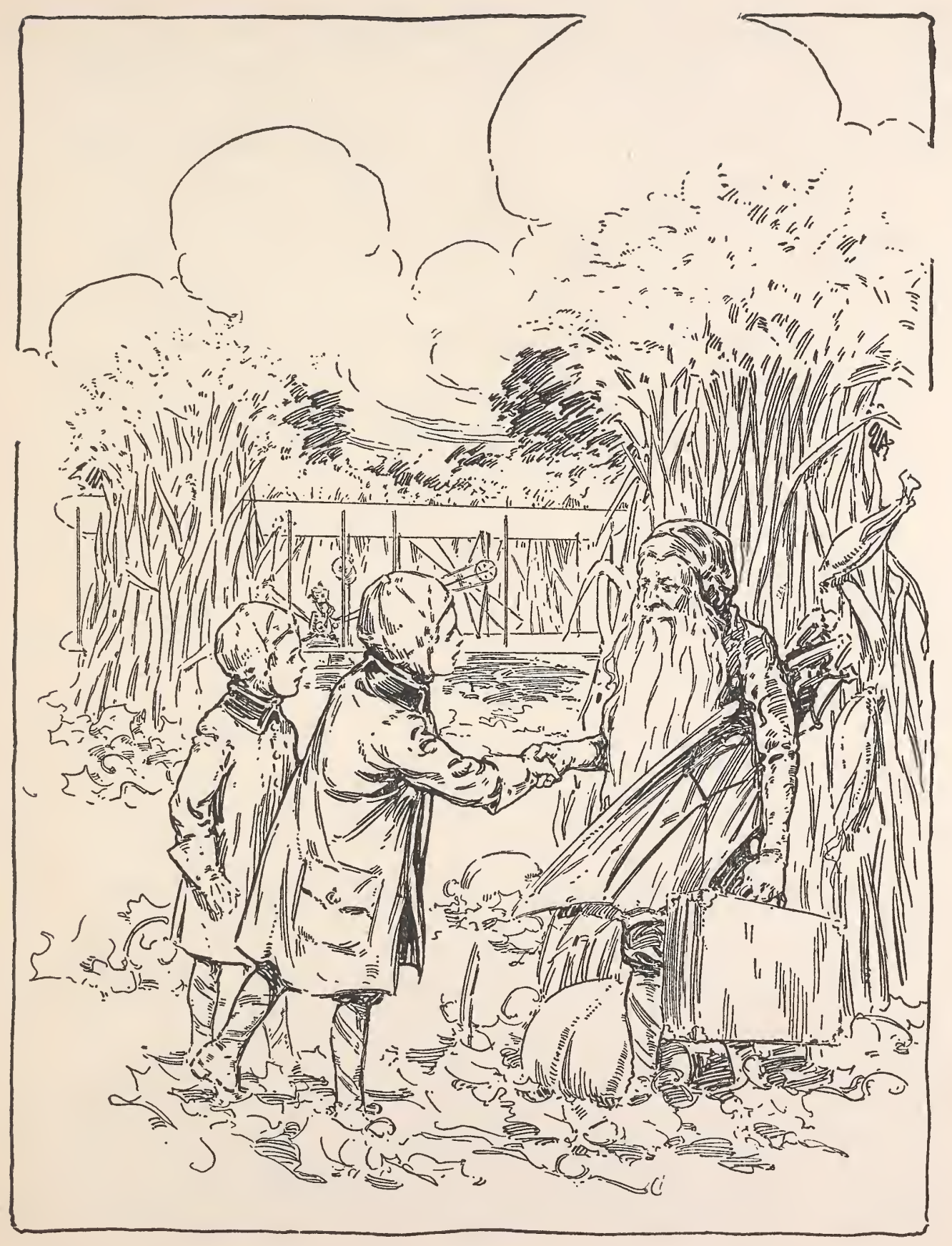




\section{CHAPTER III}

\section{The Flight Brothers}

The two daring young aviators, after reaching a height of several hundred feet, steered the biplane due west. Boy-fashion, they let it go full speed, little realizing the number of miles it was covering.

Billy, looking below, saw, in fascinated wonder, the panorama of cities, towns and villages, the vast expanses of prairie land, forests and snow-capped mountains, all apparently rushing madly by beneath them like moving pictures.

The entire day this strange and exhilarating experience held the boys enthralled, so that they forgot to be hungry or to slacken their speed; they did not even know that when rushing through the air so swiftly their breathing was made difficult and they 


\section{The Flight Brothers}

were fairly gasping for breath; and did not realize they had hardly moved from the one position since morning and their muscles had become sore and rigid.

The sight before them of an immense body of water, into which the sun was setting in a red and gold glory, finally brought them to their senses.

"Billy," cried Jack, "my fingers-are stiff-I can't stop her, and we've got to land before -we get to water."

Billy grabbed the wheel and in some way lessened the speed, but by this time the land was several miles behind. However, he managed to turn the machine completely around; then Jack took the wheel again and steered back in a long, downward glide to the ground, alighting beside a country road. The trees, some of them as big around as small houses, were the largest the boys had ever seen. After looking about them they stepped stiffly from the machine.

"Whew!" ejaculated Billy. "I feel as if my nose were blown down flat on my face."

"And my ears," laughed Jack, "feel as if they were blown clear to the back of my head. Let's 


\section{The Flight B rothers}

run a little race and try to get limbered up a bit." "All right," said Billy, and together they trotted down the road, at first running like wooden dolls; but soon the stiffness was gone and they raced back to the aeroplane. Suddenly hearing the sound of horses' hoofs, the aviators hid behind a large tree and, peeking out, saw coming around a bend in the road, a carriage drawn by two beautiful white horses. Very carelessly they had forgotten to cover the aeroplane, and there it stood in plain sight not fifty feet away. The carriage was driven by a man in a purple suit who sat very straight and high, and looked neither to the right nor to the left. In the back, crouched in one corner of the seat, was a little girl about twelve years old with red curly hair. Her head was in her arms and she was crying as though her heart would break, while on the seat beside her sat a huge, fluffy, black Angora cat. It had a manner, grand and haughty, that would take an alley cat a nine-lifetime to acquire. The carriage passed quickly by and the aeroplane remained unnoted, so the boys went to it and threw the cover over with the green side out. 


\section{$\underline{\text { The Flight Brothers }}$}

"My, but I was afraid that fellow would see the aeroplane," said Billy.

"He looked as though he wanted to cry, too," remarked Jack. "Wonder what was the matter with the little girl."

"Oh, what's the difference?" replied Billy. "You don't need to worry over a red-headed girl - and bawling at that. Come on. Let's see if we can find some grub. I'm just about starved."

"So am I," said Jack, forgetting the girl. "Let's see what we can find in the chest."

Looking for something to eat, the boys discovered two things the Little Brown Man had not mentioned: a map and a pair of field glasses.

However, they did not spend much time in inspecting these as they were very hungry. The food consisted of a large box of hard-tack and several flasks of water. They drank some of the water and ate some of the hard-tack, but did not find it very palatable. They then lay down on the ground and went to sleep under a tree. Billy, however, was soon awake; he felt restless. The moon was just rising and the 


\section{The Flight Brothers}

shadows were deep and dark. The noises of the night made him feel just a trifle afraid, much to his disgust, and he aroused Jack.

"What's that? What's that?" cried Jack rising with a start. "Say, where are we?"

"I'm sure I don't know," said Billy.

"Oh," laughed Jack, "I remember. I thought we were at home."

"Doesn't look like it," replied Billy shortly. "Let's take a walk."

"Come on," said Jack, and together they walked down the road.

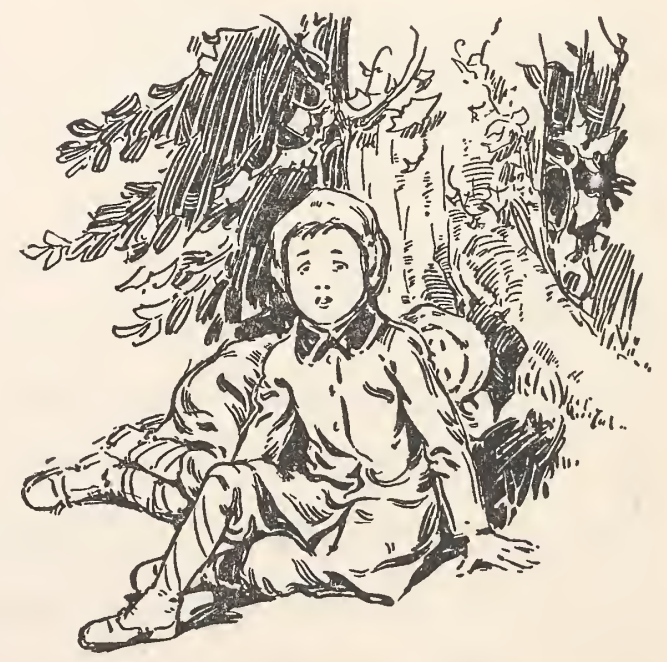

After going about half a mile they saw, directly before them, two tall iron gates in a stone wall which evidently surrounded an estate. Opening the gates cautiously, they followed a driveway which brought them to a large and beautiful house. The veranda, well lighted with electricity, was comfortably furnished 


\section{The Flight Brothers}

with chairs and swinging couches; on several tables there were baskets filled with tempting fruit.

Peeking out upon this scene from behind a bush, they saw a little girl, followed by a large black cat, come through the front door and throw herself into a chair and burst out crying.

"Huh!" grunted Billy in disgust. "It's that redheaded kid again and she's still bawling."

"Be quiet," whispered Jack, hiding behind a bush and pulling Billy after him, as a tall, thin woman appeared in the doorway.

"Doris," she cried peevishly, "if you don't stop that crying you'll drive me crazy."

"I want to see Daddy," sobbed the little girl.

"Well, you missed the boat and now you can't see him," replied the woman angrily. "That's all there is to it, so for mercy's sake be quiet. You and that black beast have given me an endless amount of annoyance. I'm very glad, indeed, that I haven't any troublesome children of my own."

"Oh, Aunty, I don't see how you can be so mean."

The woman closed the door without replying. 


\section{The Flight Brothers}

Jack was sorry for the little girl and wanted to help her if he could, so making his way carefully to the edge of the porch, he spoke to her in a low voice.

"Oh, little girl," he said. "What's the matter?"

"Who is that?" she asked sharply.

"Sh-h-h," cautioned Jack, for he had no wish to encounter the cross aunt. "Come on out here!"

The child hesitated a minute, and then, drying her eyes resolutely, came down the steps.

"Come here," said Jack from behind a bush.

She seemed frightened but obeyed him.

"Oh," she exclaimed with a little relieved laugh when she saw Jack and Billy, "you're only two boys. I thought you might be a burglar or a kidnapper, but I didn't care very much, 'cause I'd rather be kidnapped than stay in this place. Let's go down the road, for Aunty might hear us talking here. I'm so glad to see you," she rattled on, "whoever you are, for I've been so lonesome."

She led them out through the iron gates.

"Were you crying just because you were lonesome?" inquired Jack politely. 


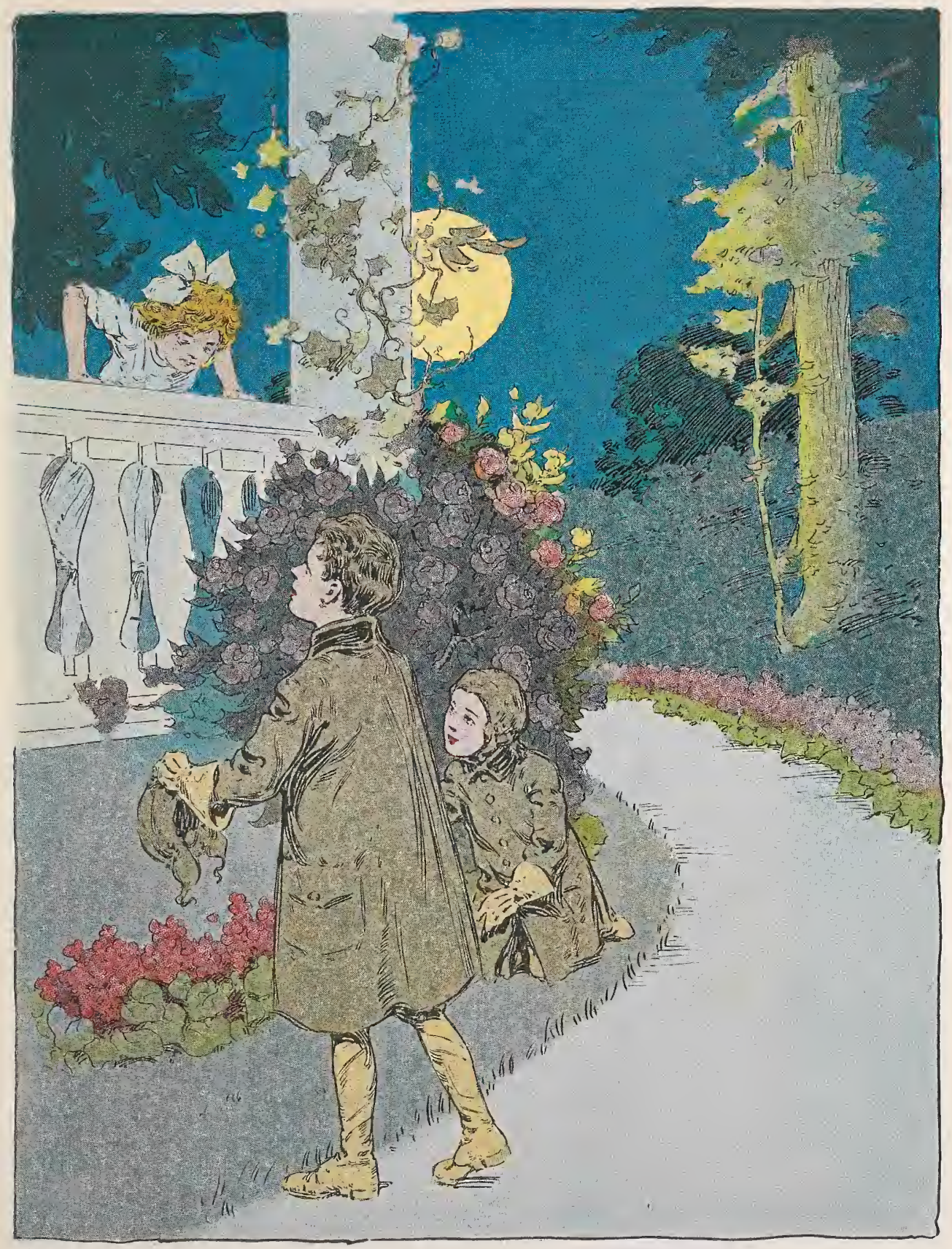





\section{The Flight Brothers}

In the moonlight the boys saw the little girl's eyes fill with tears, and Billy turned impatiently away, thinking:

"I don't much blame her aunt, if she cries all the time."

"No, no, it wasn't that," she answered with an effort. "Mother was visiting some friends in San Francisco and left me here with Aunty for a few days. To-day Mother received word from Honolulu, where we live, that Daddy was very ill, and to come at once. Mother had just an hour to catch the boat and she sent for me, but I was just ten minutes too late, for the boat had gone, taking my dearest mother with it, and I'm so worried about Daddy."

“That's fierce luck," said Billy, now sympathetic. "Wish we could help you."

"I don't see," said Jack thoughtfully, "how you could catch a boat leaving San Francisco on such short notice."

"Why not?" asked the girl in surprise. "It is only a few miles from here."

"What?" cried the boys. "Why, where are we?" 


\section{The Flight Brothers}

"Don't you know where you are?" asked the girl, opening her eyes wide in astonishment.

"No," admitted Jack.

"You're in California; a few miles from San Francisco. Are you lost?" she asked.

"No," said Jack. "We started on a trip around the world this morning in our aeroplane, and didn't know we had gone so far."

"Your aeroplane!" she gasped. "Why, who are you?"

"We are $\mathrm{Ja}$-" began Billy.

"We are the Flight Brothers," interrupted Jack quickly, giving Billy a significant look.

"The Flight Brothers?" she echoed. "Seems to me I've heard of you."

"This is my brother, Wingbird," explained Billy hastily. "And I am Soarwell."

"Oh, I see," said the little girl. "Yes, your names sound very familiar."

"Oh, say," cried Billy suddenly. "We'll take you to Hololuna."

"Honolulu," corrected the girl. 


\section{The Flight Brothers}

"We'll take you to Honolulu in our biplane, and you'll get there before the boat."

"Great!" agreed Jack with enthusiasm.

"Would it be perfectly safe?" she asked doubtfully.

"Of course it would," they assured her.

"Well, I'd rather be killed than stay here," said she. "When can we go?"

"We'll go early in the morning," replied Jack.

"All right," said the girl joyfully. "You meet me here at sunrise while everyone is sound asleep. And now I'll run back before Aunty suspects anything. I think you're awfully nice," she added gratefully.

"We'll be here at sunrise, sure," said Jack, "and I'm glad we can help you. You're not going to cry any more, are you?"

"Oh, no," she said decidedly.

"What's your name?" asked Billy.

"Doris Raymond." And bidding them good night, she started back to the house. "Don't forget to-morrow at sunrise," she called to them. "We'll be here! Good night, Doris." 


\section{CHAPTER IV}

\section{DORIS}

When the boys awoke the next morning the sun had already risen. They jumped to their feet with a start.

"Where are we?" ejaculated Billy.

"Don't you remember," said Jack, "our trip in the aeroplane and our meeting with Doris?"

"Sure pop!" replied Billy. "The red-headed kid; and we promised to meet her at sunrise, didn't we?" "Yes, and we'd better hurry, for the sun has been up awhile."

"Here goes," said Billy. "I'm for running you a race up the road."

They arrived breathless and found Doris sitting on the ground with a basket on one side of her and 


\section{The Flight Brothers}

the big black cat in stately grandeur on the other. "'Fraid we weren't comin'?" asked Billy.

"Oh, no," she said brightly, "I just knere you would."

"What's in the basket?" inquired Jack.

"That's a secret and a surprise for you," she answered with a pretty smile. "You don't mind my cat, Niger, coming, do you? She goes every place with me."

"No, that's all right," replied Jack, picking up the basket. "Come on and we'll show you our aeroplane."

When they reached the aeroplane Jack removed the cover, displaying it to view. Doris clapped her hands in an ecstasy of admiration, exclaiming:

"Oh, how perfectly sweet! I've never seen an aeroplane half so pretty as this one."

Then Billy rummaged around in the chest and brought out some hard-tack and a flask of water.

"We'll have to have breakfast before we start," he said. "This isn't very good but it keeps us from being hungry."

"Is that the only food you have?" asked Doris. 


\section{The Flight Brothers}

"Yes," said Jack. "I'm sorry."

"Now," said she, with a mysterious twinkle in her eye, "I'll show you what's in my basket." And taking off the cover she exposed to their hungry eyes the contents. There were rows of dainty sandwiches, a roast chicken, several bottles of ginger ale, oranges, fresh figs and candy.

"Wow!" cried Billy. "You're all right even if you are a girl."

"That looks mighty good," said Jack. "But how did you get away with it?"

"I went down to the kitchen this morning at three o'clock," she giggled. "And it was such a lark, 'cause I took everything I could find that was good to eat; and I made all these sandwiches my very own self."

"Good for you!" cried the boys appreciatively.

"Now we'll have some breakfast," announced Doris. "Is the aeroplane ready to start?"

"Yes, but we'll have to get our map out and see where we are going," said Billy, and asked, "Where is Honolulu, anyway?"

"I know that it is in the Pacific Ocean," said Jack. 


\section{The Flight Brothers}

“The Pacific Ocean is a big place," laughed Doris. "Honolulu is just southwest of here in the Hawaiian Islands."

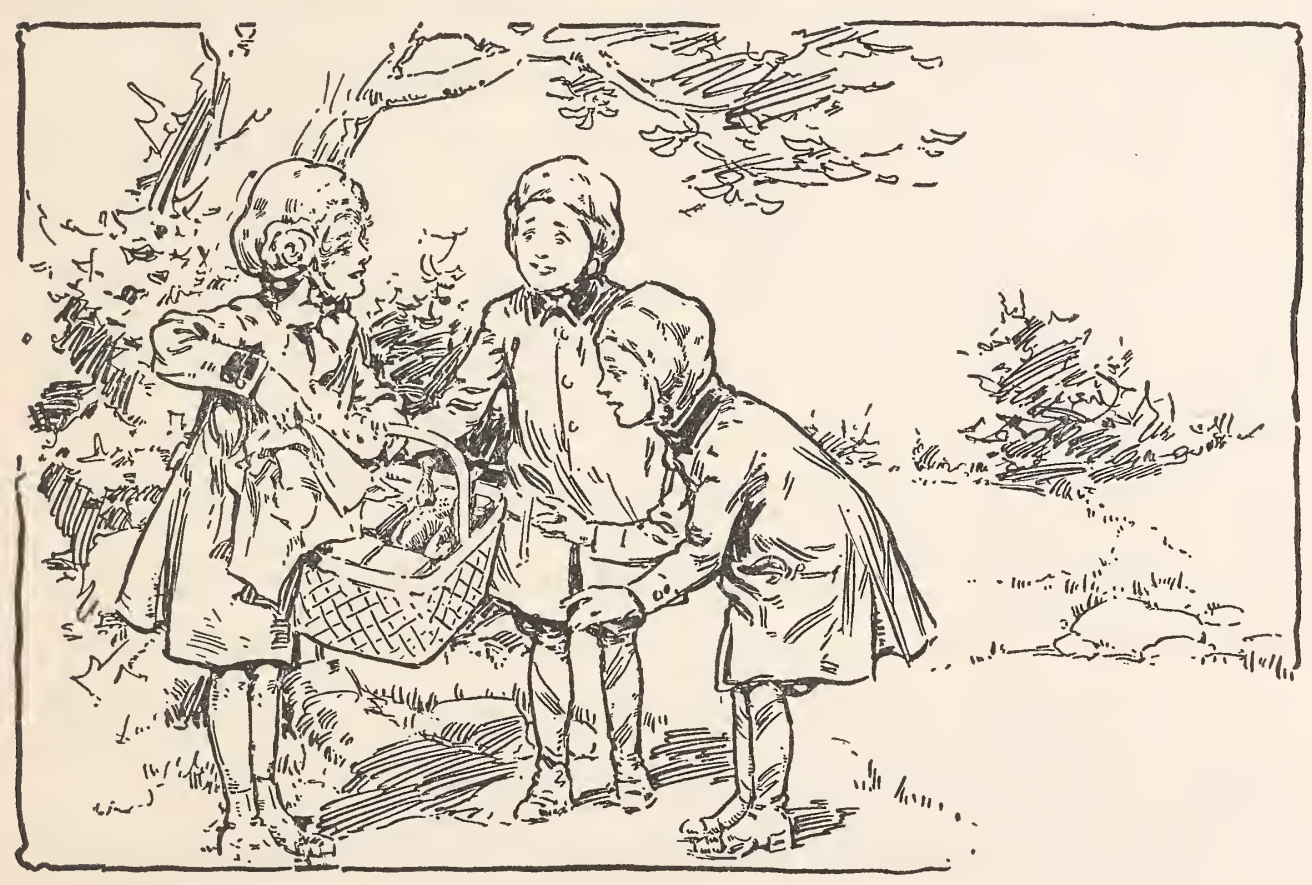

Jack consulted the map and found this to be so. They then sat down to a breakfast of sandwiches, oranges and ginger ale. I should say that the boys did most of the eating, for Doris was so excited she only nibbled a sandwich. 


\section{The Flight Brothers}

The boys then put the basket in the chest, on top of which they placed Niger. Doris was put between them on the seat. Jack started the motor; the propeller commenced to revolve and they sailed into the sky, leaving beautiful California behind them.

Although Jack did not run the aeroplane at the speed they had traveled the day before, it was, nevertheless, but a few minutes before land was entirely out of sight and the ocean spread out below them on every side.

"How far is it to Honolulu?" Jack asked Doris.

"I think it is about two thousand miles," she answered. "How long will it take us to get there?"

"Oh, we ought to be there some time to-day," replied Jack carelessly.

"Goody, goody!" cried Doris, clapping her hands with joy.

But in this she was disappointed, for night came and not a sign of land was seen. Jack was worried and explained to Doris and Billy that either they had not gone as far as the Hawaiian Islands, or else the aeroplane had been driven from its course by several 


\section{The Flight Brothers}

strong winds they had encountered through the day.

When the moon rose it was a beautiful but dreary sight that met their eyes, for there was still no sign of land.

Doris was a brave girl and kept a sharp lookout below with the field glasses.

Suddenly she uttered a cry.

"Look, Wingbird," she said pointing to the right. "There is an island."

"Sure enough," exclaimed Jack, and headed his machine full speed toward a black speck in the ocean some distance away. Doris, Billy and Niger clung tightly to their seats; in but a few seconds Jack landed them on the sandy beach of a small island.

The boys spread the cover of the aeroplane upon the ground for Doris, as she was very tired and sleepy; but first they all had a little supper from the basket, giving Niger some chicken bones, after which the three lay down and were soon in slumberland.

The next morning the sun touched the sleeping children lightly on the eyelids with her warm rays, and they awoke to find themselves in a wondrously 


\section{The Flight Brothers}

beautiful place. Behind them tall, stately palm trees rose from out of a thick mass of ferns and foliage, casting their long shadows on the sandy beach.

"Oh, what a pretty place," exclaimed Doris, adding, “but I haven't the least idea where we are. Doesn't look as though anybody lived here, but we may be near Oahu."

"What the dickens is Oahu?" asked Billy.

"Why, Honolulu is on the island of Oahu," explained Doris.

"Wonder if there are any bears here," said Billy looking around.

Doris and Jack laughed.

"Why, you silly," said she, "bears live in a cold climate, and it's very warm here."

"I'll tell you what I'll do," cried Jack. "I'll go up in the aeroplane and see how big this island is, and find out if there are any others near here."

"All right," said Doris, "but don't stay away long."

After he had gone the boy and girl walked down the beach with Niger majestically leading the way. All of a sudden the cat stood stock-still beside some 


\section{The Flight Brothers}

shrubs, and her bushy tail went up straight; then she lashed it back and forth angrily.

"Niger sees something behind that bush," exclaimed Doris stopping uncertainly.

Billy advanced boldly and looked behind it.

"Oh, jiminy crickets!" he cried, seeing a black savage fast asleep on the ground. "Look, Doris, here's my man Friday. Funny we didn't see his footprints."

"Oh, Soarwell, be quiet," whispered Doris. "I'm sure it's a cannibal, and they eat people."

Just then the savage awoke and seemed more frightened than the children, for, after one glance at them, he prostrated himself at their feet.

"I feel just like Robinson Crusoe," said Billy, pretending not to be afraid.

"Oh, Soarwell," cried Doris, catching him by the arm. "Please don't joke about it. Let's go away from here. I'm terribly frightened."

"Fine idea," exclaimed Billy as several more savages emerged from the thicket, "for here come Monday and Tuesday and all the other days of the week. Give 


\section{The Flight Brothers}

me your hand, Doris, and we'll run for our lives."

This, however, was a very unwise thing to do. The savages had mistaken these strangers for gods and were ready to fall down and worship them; but seeing the children run away in fear, they chased after and soon caught them. One tried to pick up the haughty Niger, but soon dropped her with a howl of pain, as the cat buried her sharp claws in his arm.

Doris was too frightened to utter a sound, and Billy was silent also, for the evil-looking creatures were preparing to build a fire.

"They are cannibals," wailed Doris, as she sank limply to the ground. Billy turned white with fright, but said:

"Aw, I'm not afraid."

The savages then joined hands and danced a fiendish dance around the children. In the midst of this they uttered a piercing yell and threw themselves flat on the ground. Jack in his aeroplane was returning from the sky, and, seeing the awful sight below him, turned off his motor and glided, straight as an arrow, for the savages. 


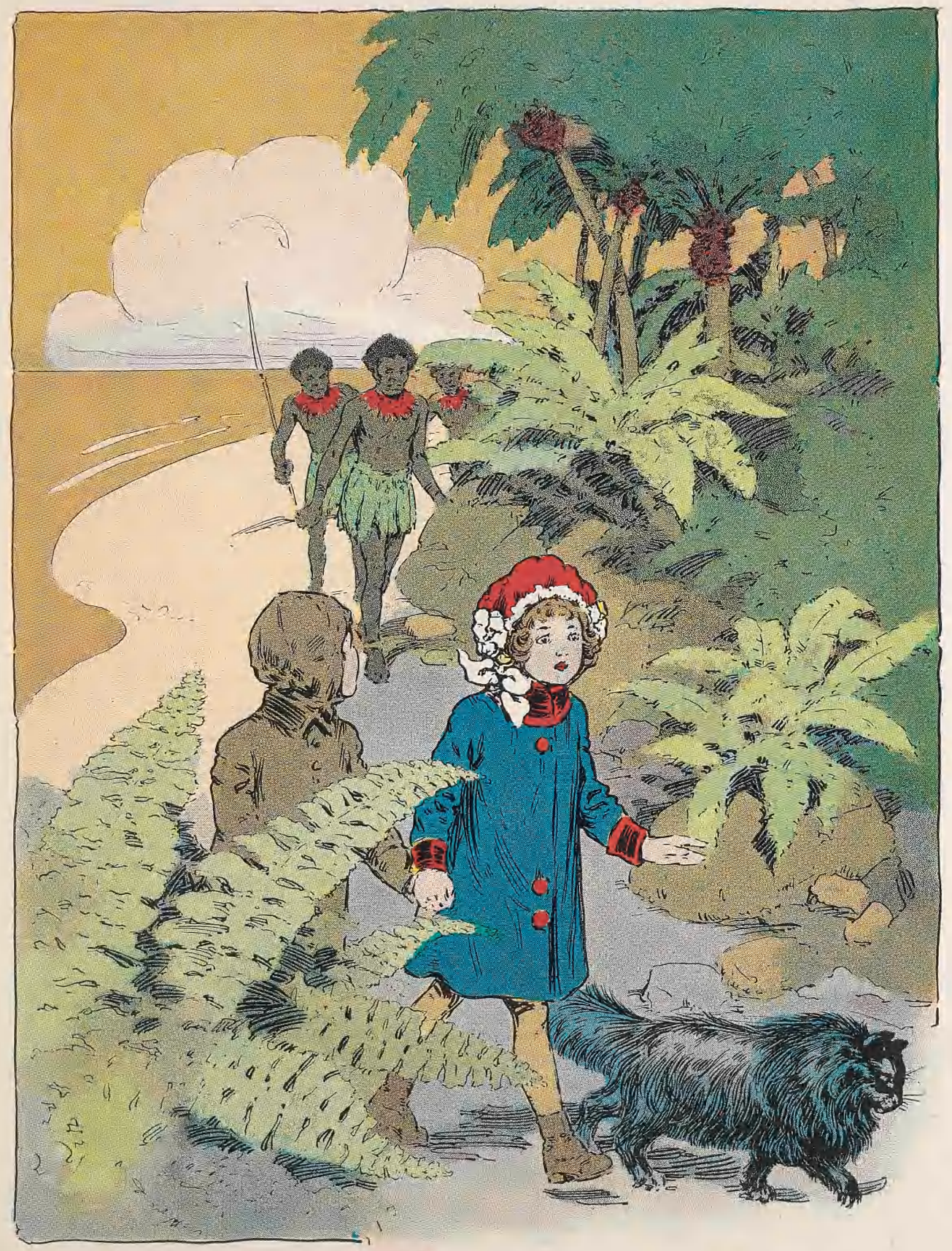


- 


\section{The Flight Brothers}

Doris attempted to rise, but was so weak that Billy had fairly to drag her to her feet. When Jack landed, the savages were terrified, for they were certain that they had invoked the wrath of a great and powerful god who had come to destroy them. Jack jumped from the aeroplane and the two boys helped Doris in, then quickly took their seats beside her, followed by Niger, who had no wish to be left.

You may imagine it did not take Jack long to start the motor again, and before the cannibals realized what had happened, the aeroplane had risen from the ground, and Jack circled around them a couple of times to add to their terror.

"Guess you won't play ring-around-a-rosey with us again," called Billy, looking back. "I'll tell Uncle Sam about you, and he'll send a warship over here to beat you up."

"How did it all happen?" asked Jack when they had left the island.

Billy explained it all, then looking at the compass, said:

"We're going north, Jack." 


\section{The Flight Brothers}

"I'm afraid we are lost," replied his brother, "but all we have to do is to put the motor on full speed and go west, and we are bound to come to something."

"Oh, look," cried Doris, pointing ahead. "There's a ship."

"Sure 'nough," said Billy. "Let's follow it."

Drawing near, they saw it was going east, so, slowly sailing high in the air, they followed it for several hours until straight ahead of them they saw land. "Give me the glasses," cried Doris; "I'm sure it's the Hawaiian Islands, and this must be the ship from Yokohama."

"Where's that?" asked Billy.

"Why, that's a Japanese city," she answered. "And this ship is probably going to Honolulu."

Then they sailed on ahead of the boat, and in a few minutes Doris pointed out to them the city of Honolulu, where it lay at the foot of the mountain; drawing still nearer the boys noted that this also was a land of gorgeous ferns and stately palm trees.

"Now, Doris," said Jack, "you tell me just where you want to land." 


\section{$\underline{\underline{T h e} \text { Flight Brothers }}$}

"We live at the very southern end of Honolulu," she said, and pointed the way.

Jack swept the aeroplane so near the earth that they brushed the tree tops at times; and when Doris caught sight of her home and gave a little happy cry, Jack circled around in search of an open space in which to land. Near the street he found a suitable spot and glided his machine to the ground.

"I must run and see Daddy the first thing," said Doris when they had alighted; "but you come right in and make yourselves at home."

At the door they were met by a trained nurse in blue and white uniform; a little brown Hawaiian woman she was with a very sweet face.

"You are Doris, I suppose," she said. "I am Miss Kanaii. Your father has been very ill, and has constantly called for you."

"Oh," said Doris, "I must go right up and see him, and tell him all about my aeroplane ride. You know, I came all the way from California in an aeroplane, with these two boys. They are Wingbird and Soarwell Flight. See, there is the aeroplane out there." 


\section{The Flight Brothers}

"Dear me," exclaimed the nurse, "I don't think you had better tell your father about that until he gets well. He might get excited and would want to know all about it; and that would not be good for him, as he isn't allowed to talk very much yet."

With that Doris and the nurse left the boys alone on the veranda.

Many people who had seen the aeroplane flying above the tree tops had followed it, and now a great crowd was gazing curiously at this strange vehicle of the air. Almost every country was represented in the crowd: there were Japanese, Chinese, English, Americans and a few of the brown natives - men, women and children -all talking and gesticulating at once.

In a few minutes Doris returned, all fixed up in a clean white dress, looking as pretty as a picture, for she was very happy now. Her short, red curls seemed happy, too, as they danced about every time she moved her head.

"Daddy has started to get well now," she told them. "He started to as soon as he saw me, and when mother gets here he will be all well." 


\section{The Flight Brothers}

A small Jap then appeared and announced luncheon, which was served in a large, airy room full of windows.

"Now," she said, with a mischievous twinkle in her eye, "I'm going to teach you something new. This," pointing to a purple-looking mess in the dishes before them, "this is poi, and you have to eat it with your fingers; all the Hawaiians do, don't they, Miss Kanaii?" she asked of the nurse who, at this minute, joined them and seated herself opposite Doris.

"Yes, indeed," was the reply.

"Look," continued Doris, "do it like this." She dipped her fingers into the bowl and drew them out covered with the food; then making a figure eight in the air with her hand, she landed the poi in her mouth.

"You did that very gracefully, Doris," said Miss Kanaii, doing the same herself.

"That's easy," said Billy confidently, attempting to follow their example. Both boys now had their fingers covered with poi and endeavored to make the same motions in the air as the other two had done. But-oh, oh, oh,-Doris shrieked with laughter, the 


\section{The Flight Brothers}

little Hawaiian nurse threw her napkin over her face, and the Japanese servant fled to the kitchen-for Billy had landed his poi squarely into one eye, while Jack's had poised for one second on his chin, then trickled down the length of his tie.

"Oh, you funny, funny things," laughed Doris. "I'll have to give you spoons after that."

The boys, having wiped the sticky stuff away, set their bowls of poi aside and finished their meal American fashion.

They had a very pleasant time, for Miss Kanaii had lived for several years in the United States and had visited many cities where the boys had also been; and she was deeply interested in their aeroplane journey. They related their adventure with the savages, but Miss Kanaii did not think they were real cannibals - much to the disappointment of the children, who preferred, now that they were safely away, to believe the worst.

The news of the arrival of the aviators in their biplane had traveled the length and breadth of the island, and the street that evening was so crowded that 


\section{The Flight Brothers}

the nurse was worried for fear the noise would disturb Mr. Raymond. Jack went out to throw the cover over the aeroplane, thinking it might attract less notice; but as soon as he appeared on the scene, the people insisted on asking so many questions that the boy became confused. One burly Englishman grasped him by the shoulder and asked:

"Look here, young fellow, how did you come into the possession of that flying machine?"

"I won't tell you!" replied Jack, shaking the man's hand from his shoulder.

"Well, that's very mysterious," was the sarcastic rejoinder.

"I should think so," broke in a couple of Americans.

"You Americans are pretty smart people," said the Englishman, "but this is the first time I ever heard of schoolboys traveling around promiscuously in aeroplanes."

"I heard they brought Dick Raymond's little girl from California in it," said one of the Americans. "Yes," said the other, "and as Raymond's friend I'm going to investigate. Looks mighty queer to me." 


\section{The Flight Brothers}

"Why, they might all have been killed, you know," said the Englishman.

"But we weren't," broke in Jack sharply.

"I believe," continued the Englishman, "that they have probably taken this machine from some one's hangar, don't you know, and by sheer luck were enabled to make the trip."

Doris and Billy then joined the group.

"Doris Raymond," said her father's friend sternly, "is it true you actually crossed the ocean with these boys in that aeroplane?"

"Why, yes," replied the little girl.

"Then," he continued, "perhaps you can tell us how they came into possession of it."

"I don't know," she answered.

"That settles it," he cried; then turning to the boys, asked: "Who are you, anyway?"

"We are the Flight Brothers," said Jack with great dignity. "Wingbird and Soarwell Flight."

At this there arose a shout of laughter from the men, and the three children looked at each other with a great deal of surprise. 


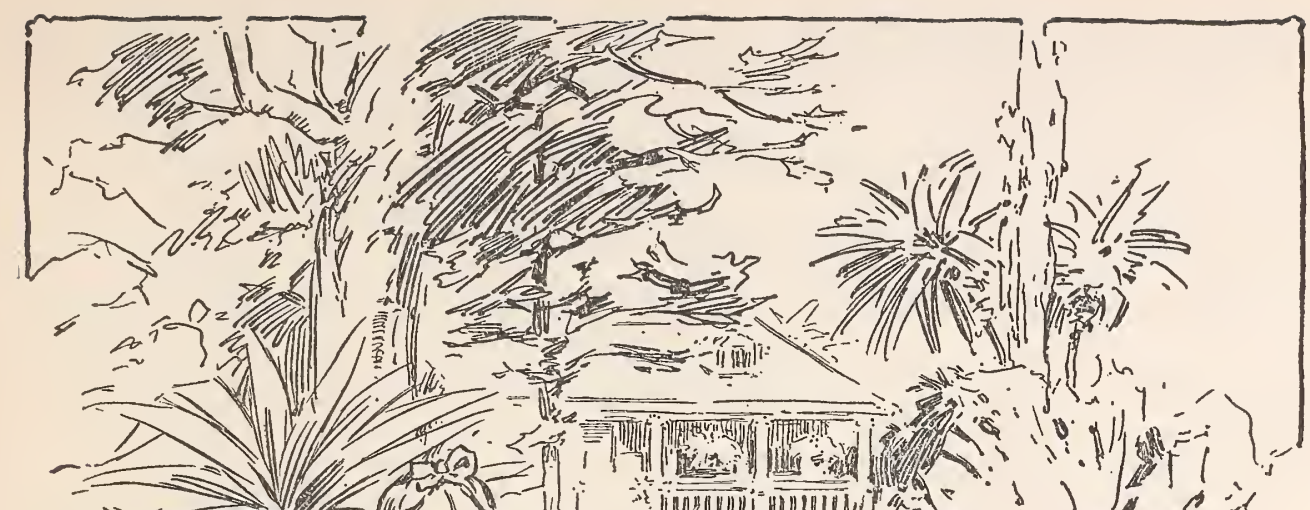

$5:=2$.

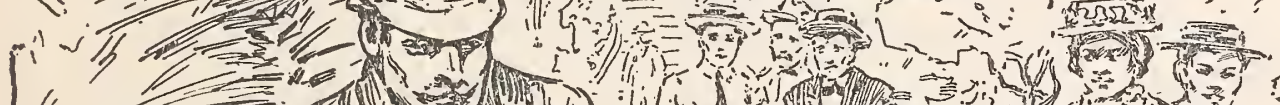

420 (1)

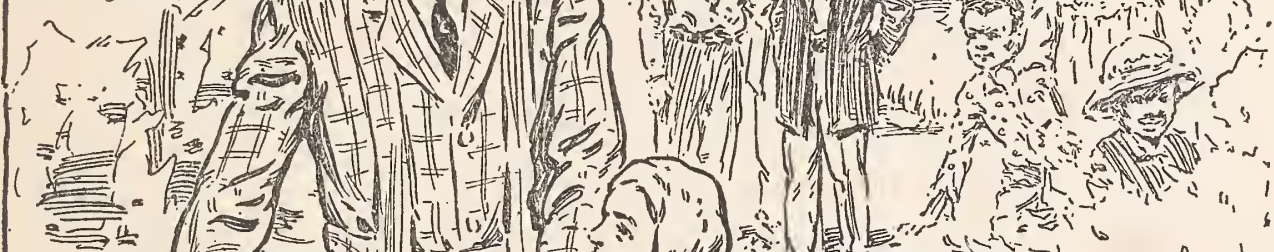

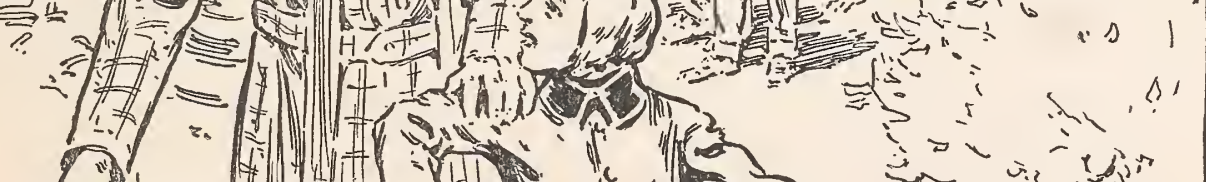

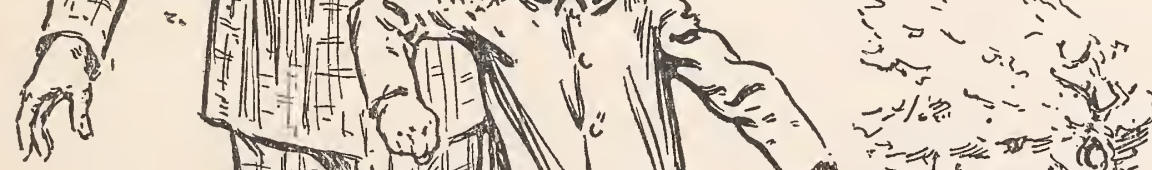

(f)

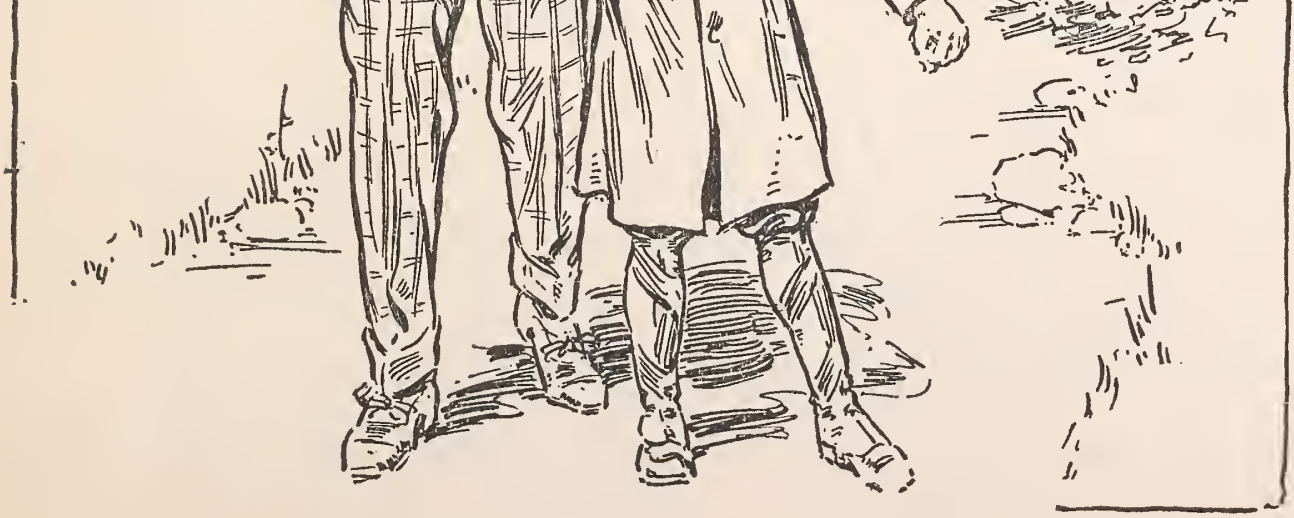

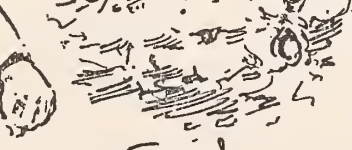




\section{The Flight Brothers}

“'They're quite celebrated," explained Doris; and at this the men laughed again.

"I think you are just as mean as you can be," she said, her red curls bobbing angrily. "Come, boys, let's go into the house."

When they were inside, Jack turned to Doris and said: "We'd better get out of here right away."

"Oh, but I don't want you to go so soon," she cried. "Yes, we have to go," returned Billy, "for these fellows are only trying to make trouble for us; and, besides, we have to finish our journey."

"Oh, here come those horrid men," said Doris in an annoyed tone as steps were heard on the veranda and a voice demanded:

"Where are those boys?"

"Wish they'd mind their own business," growled Billy.

"I'll tell you what," said Jack quickly. "Can't you let us out some other door? And then we can go around and get into the aeroplane and fly away before they know what has happened."

"Yes, I can," replied Doris. "Follow me!" She 


\section{The Flight Brothers}

led them through a small side door, and the three ran to the front of the house. The boys jumped into the aeroplane and Jack started the motor before anyone realized what they were about.

"Thank you, ever so much, for bringing me home," said Doris. "And will you write to me?"

"You bet," cried Billy. "We'll tell you all about the rest of our trip."

Just before the aeroplane rose from the ground, Doris stopped and picked up Niger, who always followed her like a dog.

"You can have Niger," she said, tossing her into Jack's lap. "A black cat for good luck, you know."

"Many thanks," they said, and as they sailed away Jack added: "We'll never forget you, Doris."

As they went higher and higher, Billy, looking down, saw the crowd staring up at the fast disappearing aeroplane, while the two Americans and the Englishman shook their fists threateningly.

"We fooled them that time," observed Jack.

"They weren't much nicer to us than the cannibals," remarked Billy. 


\section{The Flight Brothers}

\section{CHAPTER V}

\section{JIM}

As it was dusk, the boys decided not to steer westward over the open sea; so they sailed in a southeast direction among the islands, until, coming to a small one, they glided gently downward and alighted on the top of a mountain. Covering the machine, they lay down and went to sleep beneath it.

Early the next morning Jack awakened Billy and they had breakfast; as there was only one sandwich left in Doris' basket, it was necessary to return to the hard-tack and water. Jack offered Niger some, but she only sniffed at it and walked disdainfully away.

"Come on, Billy," said Jack. "Let's get away from here. We'll have to hurry."

"That's right. Time is flying and we only have 


\section{The Flight Brothers}

two weeks to get around the world in, let's remember." "Less than that, now," said Jack. "Let's seeone day gone when we reached California; two days when we reached the island with the cannibals on it --"

“One week gone," interrupted Billy, "while Doris and I were waiting for you to come and save us from them."

Jack laughed.

"It must have seemed like that," he said, "but it couldn't have been over fifteen minutes. Three days gone," he continued, "when we left Doris, last night, and this is the beginning of the fourth day."

"Well, here goes for the fourth day," cried Billy with enthusiasm. "Let me run the thing for awhile." "All right," agreed Jack, picking up Niger, and the boys hopped in.

Billy turned the motor on full speed and steered for the west. The aeroplane leaped into the air like a ball shot from a cannon. At that rate it took them about one minute to get entirely out of sight of land, and again the ocean spread out beneath them on every side in dreary monotony. 


\section{The Flight Brothers}

"Not so fast," advised Jack. "I can hardly breathe. Slacken the speed, Billy."

When night came they could see no land, although during the day they had passed a few small islands. But on these Billy absolutely refused to alight, as he did not intend to take any more chances. So all that night the boys remained in the air.

Early the following morning, while Jack was running the machine, a strong wind struck them, which blew so hard in their faces they could hardly keep their seats.

"Better hang on tight," said Jack. 'Put that howling cat into the chest before she falls off into the sea. Cats don't love water, you know."

"You put her in," replied Billy. "It's about all I can do to hang on myself."

"Well, it's up to you," said Jack. "I have to steer."

"Where you takin' us to?" cried Billy, as he closed the chest after putting the cat in. "We're going straight up."

"Can't help it, Billy," yelled Jack. "That wind 


\section{The Flight Brothers}

is certainly a corker. We're not moving a bit-engine's running full speed."

"Keep'er right side up," said Billy as the machine was slanting dangerously.

"Hang on!" screamed Jack.

No sooner had he said this than they saw the earth apparently revolving around them, as the aeroplane was turned over and over in the arms of a typhoon.

"Guess it's all off, now," shrieked Jack in an effort to make himself heard above the noise of the wind. "We're turning somersaults. This-hang on, we're goin' over again! - This is awful — wish we were home."

"Gee!" shouted Billy, "I nearly slipped. If we fell in the ocean we'd sure be drowned."

"We won't ever hit the water-or the earth again, either - if this keeps up. Guess we're gettin' blown off the earth altogether."

Around and around they went as helplessly as a feather. It had grown very dark, and the typhoon continued to rage on in fury, while the boys clung to the machine with all their might. 


\section{The Flight Brothers}

"Why did we ever leave home!" wailed Billy, but everything either of the boys said was lost in the tumult of the howling wind. The aeroplane dived and plunged like a kite, but always righted itself; it seemed as if the wind never would stop blowing. The boys were exhausted from their experience when finally it became lighter and the wind slackened; then the machine plunged forward again, and down - down - down.

"You'll drown us, sure," yelled Billy. "Make her go up, Jack, quick! Pull the lever back!"

Jack tugged at the lever and, with a jerk, the machine changed its downward course and shot out over the surface of the water a few feet above the angry waves.

And then, as though wishing to add to their troubles, a blinding rainstorm broke upon them, and the boys were unable to see where they were going. Suddenly a wave swept over the aeroplane, drenching them. Jack jerked the lever backward and they commenced to go up with the rain beating in their faces. In a few minutes they became aware of the fact that 


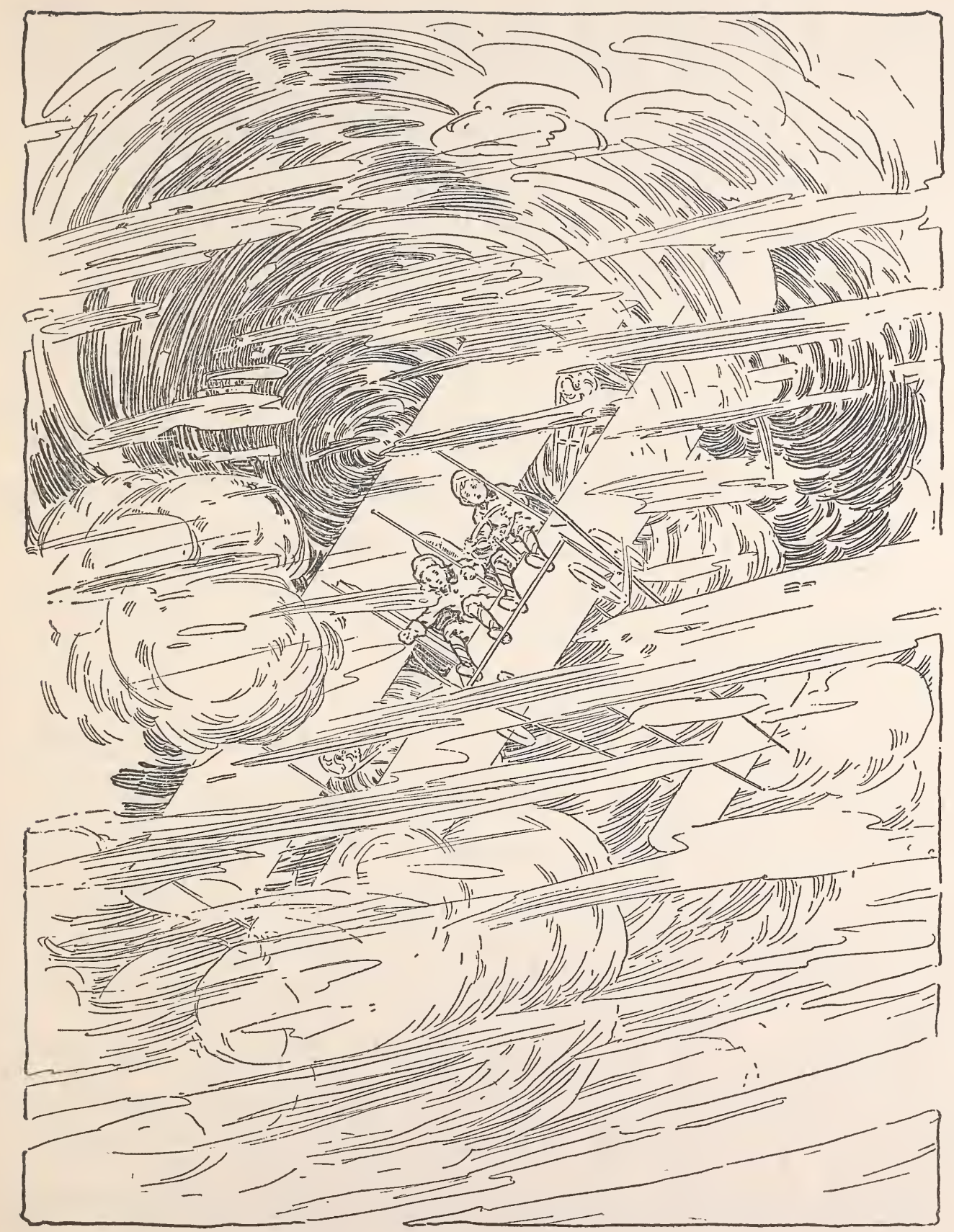




\section{The Flight Brothers}

it was no longer raining; the sun was shining brightly, although boys and aeroplane were dripping with water; but looking below they saw the storm still raging.

"What do you think!" exclaimed Jack. "We are up above the clouds."

"Sure enough," cried Billy, excitedly. "Next time we see a storm coming we'll know how to fool it."

"It certainly tried mighty hard to put us in the ocean. I'll bet any other aeroplane would be smashed to smithereens."

"Course it would," said Billy.

The air was very much cooler above the clouds, and as the young aviators were drenched to the skin, they decided to put the cover of the aeroplane around them to keep warm. When they opened the chest, what a sight met their eyes! Everything was topsyturvy. The things that had been on the bottom were now on top; and the things that had been on top were now on the bottom; so that poor Niger who had been on top was now hidden-all but her head. They dragged the poor cat out and put her on the chest 


\section{The Flight Brothers}

again, and there she sat looking very much annoyed. "Aw, that cat makes me tired," said Billy. "She puts on enough airs to be the king of England."

In the afternoon the boys, who were already chilled with the cold, saw, to their dismay, a snowcapped mountain peak protruding high above the clouds.

"Gee, I'm about frozen," said Billy, his teeth chattering. "And that looks like the North Pole."

"Perhaps it is. Let's see," said Jack, pushing the lever forward, and the aeroplane shot down through the clouds. As the boys drew near the earth the air became so hot and sultry that they were nearly stifled and had to remove their coats.

"This is no North Pole," said Billy, wiping the perspiration from his face.

After leaving the mountains behind, the aeroplane sailed south over dense forests and jungles. In a couple of hours, seeing before them a most picturesque and beautiful city, they decided to visit it, and glided to the ground in a secluded spot about two miles away. After alighting, the two boys and the 


\section{The Flight Brothers}

cat went on foot to the city. There the sights they saw forced many an "Ah!" and "Oh!" from their lips. The people were very dark skinned and thinly clad. They walked down one street, lined on either side with small, peculiar houses, then turned sharply into a busy market place, where they saw several people of their own kind. The boys, remembering their experience in Honolulu, preferred to pass unnoticed. Walking on, they saw some funny, covered vehicles drawn by animals that looked like cows. Next, they could hardly contain their joy at seeing a large automobile, surrounded by a number of black men who were evidently trying to sell their wares, which consisted of silk shawls and bits of jewelry, to the occupants. Farther on they turned into a deserted street, and soon came upon a strange sight. Beside a bush a black man sat on the ground playing a weird tune upon an odd little instrument. In front of him was coiled a snake, its head lifted and its small beady eyes gazing fixedly at the man as though fascinated by the music.

Niger crouched for a second, then, springing, 


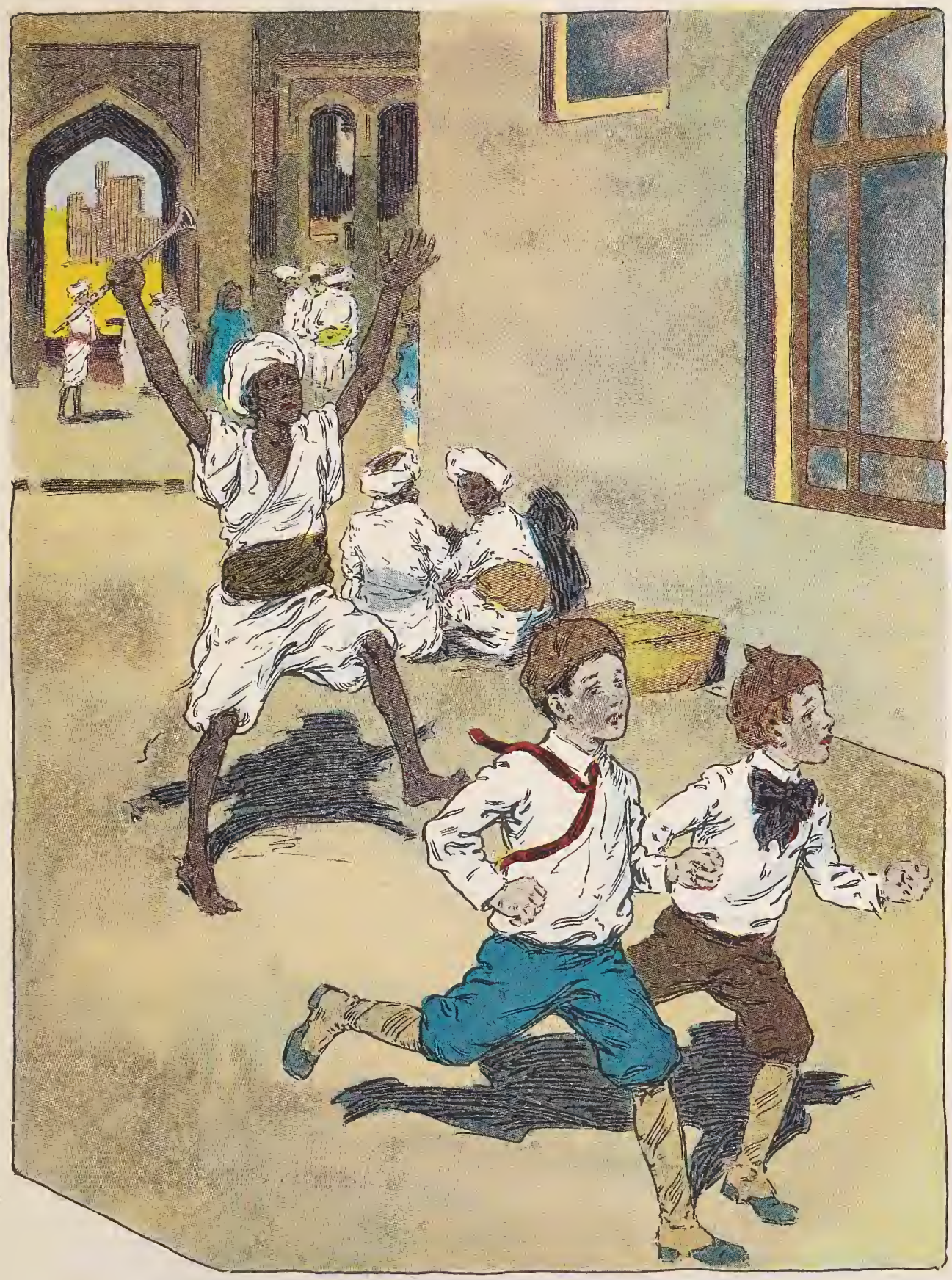





\section{The Flight Brothers}

grabbed the snake by the head and ran down the street and around a corner. The man jumped to his feet, and waving his arms wildly above his head, danced up and down in a frenzy. At his strange actions the boys became frightened and started to run with the man after them.

"Gee, maybe he's a cannibal too," said Billy.

"Oh, no," replied Jack, and just then a couple of gold pieces which he had taken from the chest before coming to the city, fell from his pocket. The man stopped and picked them up, and they saw no more of him.

Niger was waiting around the corner, and whether she ate that snake or whether it got away from her, the boys will never know, for she was sitting unconcernedly washing her face.

They then turned down another street where the houses were decidedly American in appearance. Coming from the opposite direction was a boy about Billy's size, with an ugly white bulldog at his heels.

"Ha, ha!" cried the boy, catching sight of Niger who was in the lead. "I say, get that cat, Clutch." 


\section{The Flight Brothers}

Niger did not move. She only stood still and calmly regarded the dog with her green eyes as he stopped uncertainly in front of her. Cautiously he took another step toward her. Niger humped her back, crouched and sprang directly upon the dog's back. With a howl of pain he commenced to run and Niger sprang lightly from his back and resumed her walk.

Jack and Billy laughed immoderately, while the other boy grew red in the face with mortification for his cowardly dog.

"Are you two old maids traveling through India with your cat?" asked the boy, insultingly, as he leaned against a tree and regarded them in a superior manner.

"Oh, is this India?" asked Jack, ignoring the unfriendliness of the other.

"Yes, this is India," he mimicked. "What did you think it was? The Strand?"

"You're too fresh," remarked Billy.

"I say," replied the boy, doubling up his fist, "perhaps my dog can't fight your silly cat but I could fight you, you know." 


\section{The Flight B rothers}

"Come on," said Billy.

Without further delay the boy planted his fist in Billy's forehead; Billy promptly returned the compliment in the other's eye.

It might have been a fight to the finish had not both boys been nabbed by their collars, as a woman's voice cried:

"I'm ashamed of you, James Harcourt. How can we expect to teach these natives to be Christians when you continually insist on giving these exhibitions in the street. Now this is the third time I have caught you, and I'm going to tell your father. As for these other boys - Who are you?" she asked, turning upon them.

"The Flight brothers," replied Jack politely.

"Who?" she asked again.

"The Flight brothers," repeated Jack. "Wingbird and Soarwell Flight."

"Fiddlesticks!" ejaculated the woman brusquely. "You're Americans, aren't you?"

"Yes."

“Well, it's a wonder you wouldn't wash your faces 


\section{The Flight Brothers}

and brush your hair. I never saw such untidy boys." Jack and Billy looked at each other guiltily, remembering for the first time since they left home that they had washable faces and brushable hair. So many exciting adventures had caused them to forget many everyday things, such as eating even-at times.

The woman, warning them not to fight again, went her way and the boy seemed to be in a friendlier mood.

"You're a good fighter," he informed Billy.

"So're you," returned Billy.

"I'm English-from London. My name's Jim Harcourt," volunteered the boy. "That was Miss Smith, a missionary. I don't much care if she does tell my governor, but mother doesn't like to have me fight."

"Neither does ours," said Billy.

"Let's sit down," said Jim.

The three boys threw themselves down on the grass and were soon exchanging confidences. Billy and Jack related the story of their adventures, not mentioning, however, the Little Brown Man. Jim 


\section{$\underline{\text { The Flight Brothers }}$}

listened to this tale with his eyes as big as saucers and his mouth wide open. He invited the boys to stay with him for a few days, promising them all sorts of things if they would only let him see their aeroplane; and this the boys agreed to do.

Jim, taking them to his house, left them on the steps while he went to look for his father. When he found him he told him all about the Flight Brothers.

"Oh, these Americans," laughed Mr. Harcourt when Jim had finished. "How far behind the times we are out here in India. So schoolboys are traveling in aeroplanes, over in America, are they? I've heard these machines were dangerous. Well, bring your friends in, Jim. I shall consider it an honor to entertain them royally while they are here."

Mr. and Mrs. Harcourt welcomed the boys cordially, accepting their assumed names without question. Jim's mother took quite a fancy to Niger, pronouncing her the most beautiful cat she had ever seen. And it amused them all to see with what great respect the bulldog, Clutch, now treated her.

The next morning Mr. Harcourt took the three 


\section{The Flight Brothers}

boys elephant riding, and showed them some of the wonders of India.

In the afternoon they were left alone with Jim, and the three decided to go and get the aeroplane, but Jim's mother forbade her son to accompany them, as she doubted the safety of their machine. So Jack and Billy started off without him. It took the young aviators about two hours to find the aeroplane, so well was it hidden. As they were removing the cover and preparing to start, they heard a deep growl and, looking up, saw, not ten yards away, an immense tiger.

"Tigers!" gasped Billy.

"Jump on here, quick!" commanded Jack, taking his place at the wheel and starting the motor; but they were not quite quick enough. The tiger leaped and caught the machine in mid-air just as it was leaving the ground. For an instant the animal clung uncertainly to the bottom plane between the two boys. Jack had turned the motor on full speed and the tiger was carried up hundreds of feet before it loosened its hold, and falling on the rocks beneath, was instantly killed. The boys circled around until quite certain that 


\section{The Flight Brothers}

it was dead, then glided to the earth and attempted to get the carcass aboard. As it was very heavy, it took them an hour of hard work to get it on the aeroplane. By that time it was dusk and the forest was filled with howlings and the peculiar noises of wild animals out for prey, so the young aviators were indeed glad to leave that dangerous district. In five minutes more they landed in front of Mr. Harcourt's residence. Jim, who had been scanning the sky for a couple of hours, was overjoyed to see them.

Mr. Harcourt, on hearing about the tiger, was astounded.

"You are certainly wonderful boys," he said. "Oh, these Americans!"

The next day the boys were the undisputed heroes of the town. Many people, both English and Indians, some of high degree, came to see the aeroplane and hear about the tiger, whose skin Mr. Harcourt was having made into a rug.

In the afternoon the boys made an exhibition flight which was very spectacular. Jack, who was at the wheel, made some wonderful figure-eights in the 


\section{The Flight Brothers}

air and entertained the people. The English cheered him repeatedly, while the natives watched in silent wonder.

On the following day it was so hot that wet blankets were hung up at the south end of the veranda to keep off the burning wind. Everyone was content to remain quietly indoors, except the young aviators, who suggested to Mr. Harcourt that they all go up in the Perfect Aeroplane above the clouds where it was cool. Mrs. Harcourt refused to be enticed off of the earth, but Jim and his father went and they had a great time. Mr. Harcourt called it "sky-larking."

On the following morning the boys decided to continue their journey, much to the disappointment of Jim. Before they departed Mr. Harcourt presented them with the tiger skin which he had had made into a rug; across the neck was a strip of silver in the form of a collar, and on this was engraved with the date:

Killed by the Flight Brothers in India.

An Indian prince of great wealth, who had witnessed their flying, hearing of the intended departure, sent them a string of priceless rubies. 


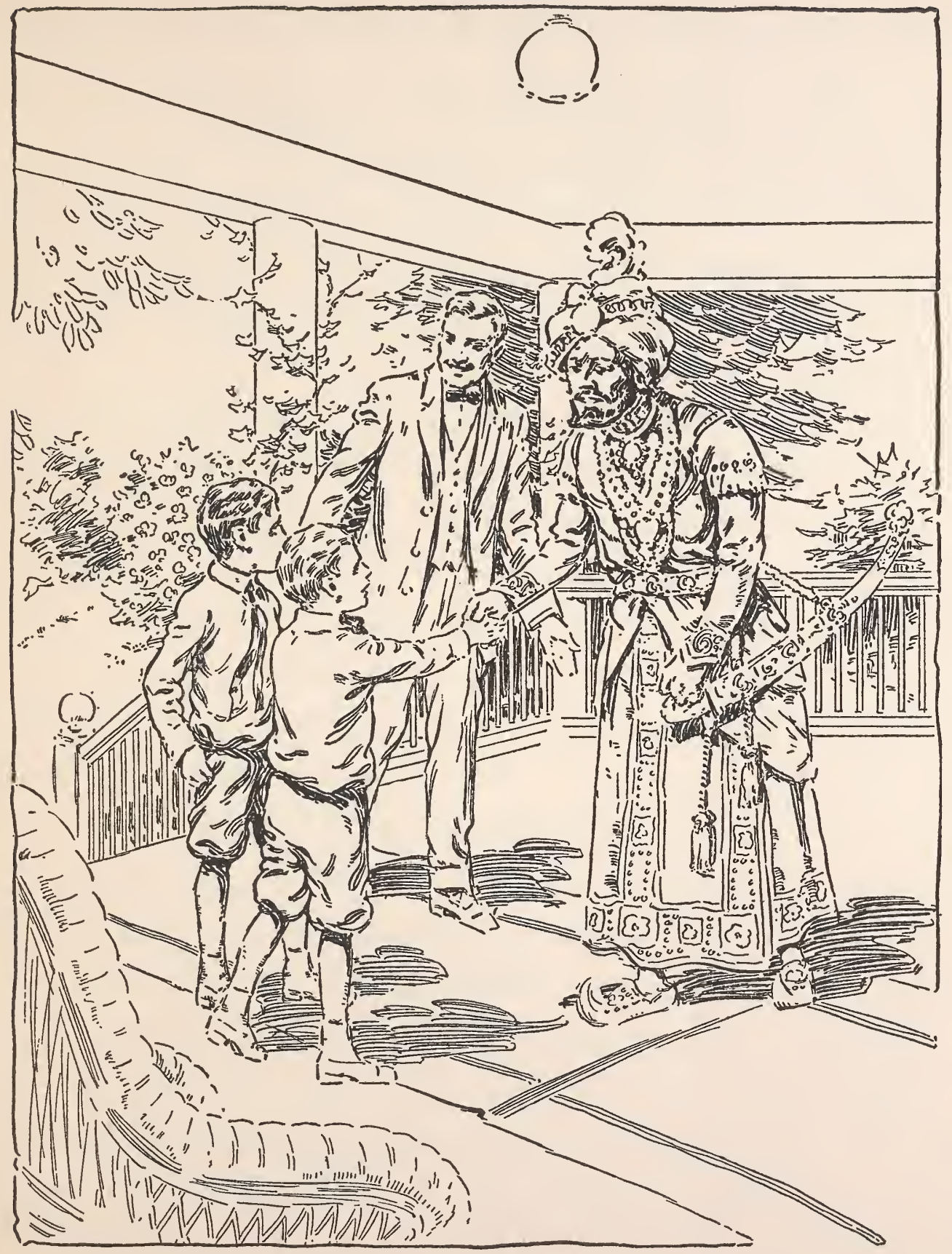




\section{The Flight Brothers}

Mrs. Harcourt was more practical and put a basket, full of the things boys like most to eat, in the chest on the aeroplane. At last, after all the goodbyes were said, Jim, not to be outdone, presented the boys with his dog, Clutch, who he declared was afraid of nothing - but cats.

And so on this, the morning of the ninth day since they had left home, the Flight Brothers flew away from India towards the sky, leaving many admirers behind. 


\section{CHAPTER VI}

\section{The Wrecked Aeroplane}

All that day the boys traveled above the clouds where the air was cool. Towards evening they glided down to the earth again beside a beautiful river. On the opposite shore rose a high rocky cliff in the side of which sat what appeared in the twilight to be four immense giants.

"Giants!" said Billy in an awed tone.

"There's no such things," scoffed Jack. "Let's go and have a look," and he started the motor again and steered directly for them. When the boys drew near they discovered that the giants were four enormous statues, one of which was headless, guarding a doorway leading into the interior of the cliff.

"Let's land and go in," suggested Jack. 


\section{The Flight Brothers}

"Not—on-your—life!" said Billy. "You can't tell what might be in there."

“That's so," replied Jack, and steered the machine for the sandy shore opposite.

After alighting, the boys ate a large portion of the contents of the basket Mrs. Harcourt had given them. Jack fed Niger and Billy fed Clutch and then the four curled up and went to sleep beside the aeroplane.

In the morning they were awakened by the sound of some one shouting, and jumping to their feet they saw coming towards the shore an odd but picturesque sailboat filled with men who wore white turbans and were as black as the ace of spades.

"I would not take a chance on them," said Jack.

"I should say not," agreed Billy, and they jumped aboard the aeroplane, dragging Niger and Clutch after them.

Jack turned on the motor and in a few seconds the biplane whizzed toward the sky until the river looked to them like a silver thread below.

"Say, Billy," said Jack suddenly; "we've been 


\section{The Flight Brothers}

away ten days and I can't imagine where we are; so let's fly west without stopping until we get to the United States."

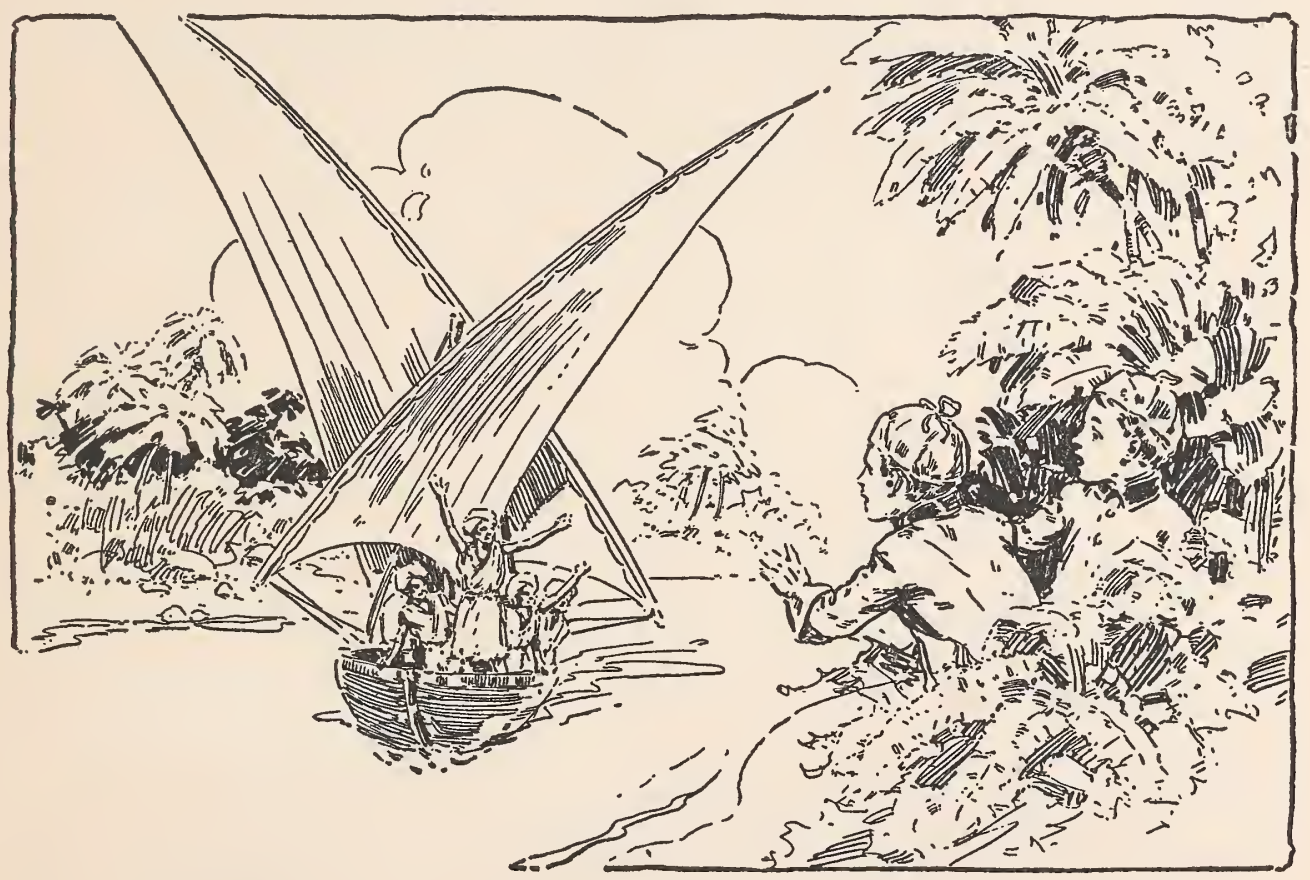

"All right," replied Billy, "'cause we want to be back when the Little Brown Man said to." "Of course."

All day they traveled across a sandy desert. Once, seeing what appeared to be a string of large ants 


\section{The Flight Brothers}

below, they sailed down but found that it was a caravan of camels. They flew quickly up to the sky again, as the heat was intense. And then they sighted a pretty green spot in the midst of the dreary waste of sand, and sailed down to inspect it, and here finding a spring, filled their water flasks before leaving.

Night came and they were still over the desert, so they took turns running the machine. About midnight the desert was left behind and soon after, they came to the ocean. Jack concluded it was the great Sahara Desert which they had crossed, so he changed his course to northwest.

On the morning of the twelfth day the aviators sighted the statue of Liberty in New York Harbor. Although their trip had been full of adventure and pleasure they shouted with joy.

"All the places we've been were beautiful and interesting," said Jack, adding fervently, "But there's no place that makes you feel so good as the United States, is there, Billy?"

"I should say not," said Billy decidedly.

They passed over a countless number of ships in 


\section{The Flight Brothers}

the harbor; they sailed over the busy city, and on over the country lands. They were not flying very fast and evening found them about four hundred miles from New York. They landed in a small open space on the banks of a river. It was not very picturesque compared with what they had seen in their travels; there were no palm trees nor luxurious tropical plants; but the boys felt safe as they curled up on the tiger skin for the night.

Niger, after her forced confinement in the aeroplane, went prowling about to try to catch a stray mouse or gopher; but Clutch preferred to stay with the boys, and stretched himself out comfortably between them.

"I'll tell you what we can do," said Jack before they dropped off to sleep; "let's give the string of rubies to Mother and the tiger skin to Father."

"Sure thing," agreed Jack drowsily.

They awoke late the next morning and breakfasted on hard-tack, which was the only food they had left. At noontime they took off their clothes and went in swimming. Clutch yelped and dived in after them, 


\section{The Flight Brothers}

much to the disgust of Niger, who watched disdainfully from the bank.

In the afternoon the boys sailed on, and soon came to a large body of water, as smooth as glass.

"Lake Michigan," they both cried together.

Approaching the shore, they heard a faint cry for help, and, looking below, saw at the foot of a sand dune, a mass of tangled wires, bars and cloth.

"A wrecked aeroplane!" exclaimed Jack.

"Sure enough! And some one under it," said Billy.

It took them but a few seconds to make a landing and to find beneath the wreckage the unfortunate aviator. He was absolutely unhurt, however, but had found it impossible to release himself. The boys soon freed him and the man stood up unsteadily.

"I thought I was done for," he said. "I just came over from Chicago. I wanted to be the first to cross the lake in an aeroplane. Just as I reached the shore my motor gave out and I lost my head and everything went wrong."

"Lucky you didn't fall in the lake," said Jack. 


\section{The Flight Brothers}

"Yes, but it's mighty unlucky," said the man, "to lose my monoplane. Take my advice and stay on the ground, boys. What kind of a machine have you over there?"

"Ours is safe," Jack informed him. "It's the Perfect Aeroplane."

"Yes," said the man ironically, "that's what I thought mine was."

"But ours really is. We've been all around the world in it." And he told the man of their trip and showed him the tiger skin with the inscription on the collar.

"The Flight Brothers!" exclaimed the aviator. "Is that what you call yourselves?"

"Yes," said Jack. "We're Wingbird and Soarwell Flight."

"Of course," laughed the man, "those are not your real names. But they have a very aerial sound." "Would you like to take a ride with us?" asked Jack, wishing to change the subject.

"Oh, not yet," said the man as he sat down upon the ground. "Let me see you run it first." 


\section{The Flight Brothers}

Then Jack exhibited his machine and sailed it as this aviator had never seen one sailed before. When he glided to the earth the man ejaculated:

"Well, I'll be hanged. Where did you get it?"

"Belongs to a friend of ours. He lent it to us to take our trip in."

Jack explained to him its wonderful speed and safety.

"Tell you what I'll do," cried the man excitedly. "I'll give you any amount of money you wish for that machine."

“" 'Tisn't ours," said Billy bluntly.

"Well, let's all three of us take it to the aviation meet in Chicago."

"Perhaps that would be all right," said Jack slowly.

"Why, can't you see, it will win everything in sight," said the man feverishly. "Let's start right away. And say, let's leave this cat and dog here."

"I should say not!" cried both boys together.

Jack had begun to distrust the aviator and was not very enthusiastic about taking him with them. After they were all in the aeroplane the man wanted 


\section{The Flight Brothers}

to see how fast it would go. Jack let her out almost full speed.

"Slacken up," gasped the man. "Great guns! about four hundred miles an hour, I should say. Now look here, boys," he continued, "you've got to be sensible. You must, at least, lend the aeroplane to me for-say about a week."

"Can't do it," said Billy. "We've got to return it to the owner."

The aviator pleaded and begged, but all to no avail.

"We have to play fair with our friend," Jack explained patiently, over and over.

"We simply can't do it, and that's all there is to it," said Billy decidedly.

"Oh, it is, is it?" sneered the man, and he made a grab for the boys, evidently intending to push them overboard and gain possession of the aeroplane at any cost. But-the bulldog, seeing the motion, then proceeded to prove that he was "only afraid of cats."

Clutch made a lunge for the man and, grabbing him by the leg, caused him to lose his balance, and 


\section{The Flight Brothers}

both fell out of the machine, Clutch still clinging to the man's calf. Again this man's life was strangely saved, for as he rolled over the side he grabbed a bar on the alighting gear and clung to it desperately. Jack quickly turned his machine around and glided back to the shore, and when a few feet above the ground, commanded the man to let go. Clutch emphasized the order by shaking him, and aviator and dog dropped to the ground, rolling over and over in the sand.

Jack stopped the machine a few yards away, and called to Clutch, who still seemed very reluctant to let go.

"Good dog," said Billy, patting Clutch's ugly head as he clambered aboard. "That wasn't a very nice trick to try to play on us after our saving him, was it, Jack? But Clutch fixed him all right."

"Oh, I guess the fellow was half crazy," was the reply.

"Now let's go to the aviation meet," said Billy as they flew upward, leaving the disappointed man behind. 


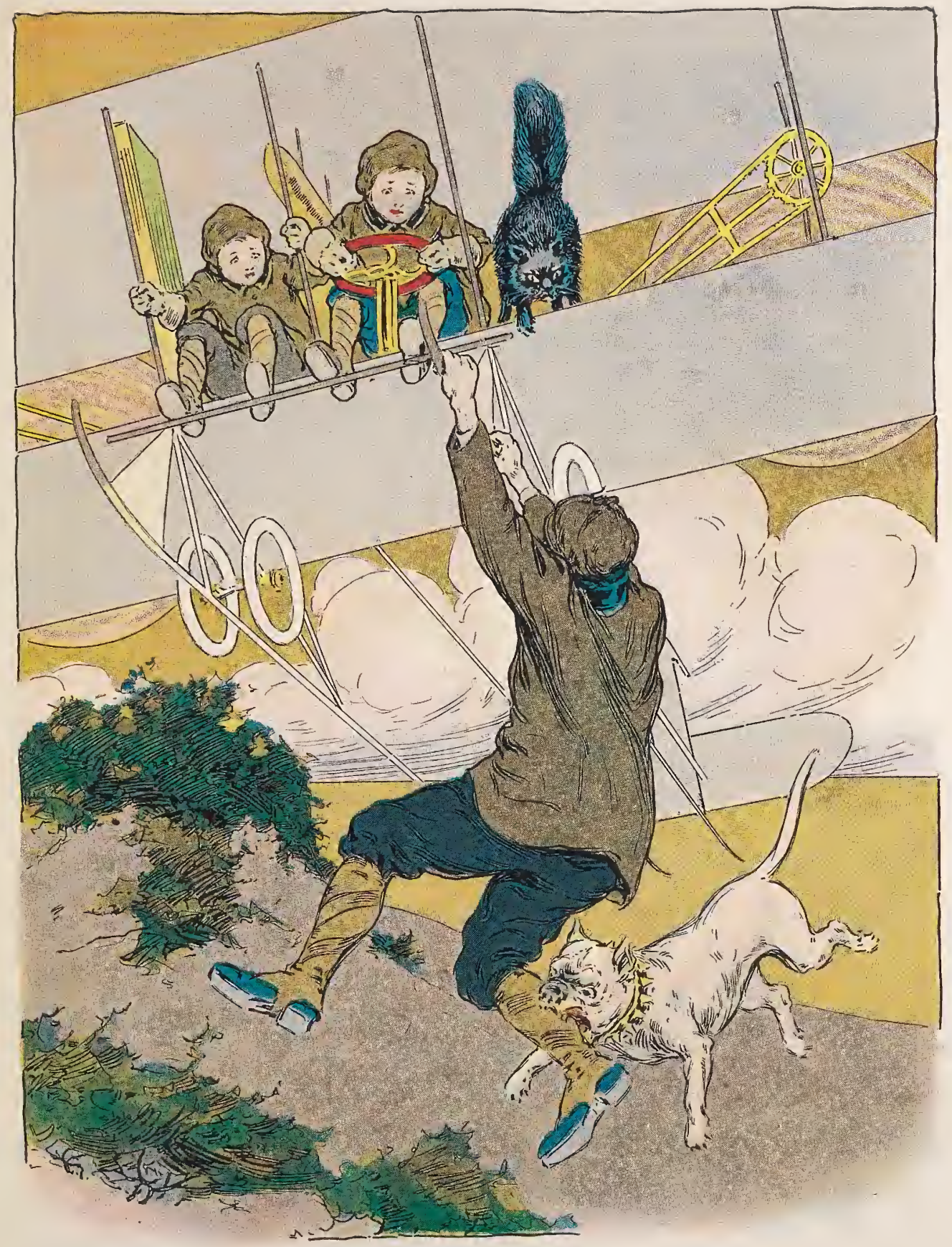





\section{GHAPTER VII}

\section{The Aviation Meet}

In a very short time they sighted land and could distinguish a smoky city on the horizon. It was not a city one would call beautiful at first glance, but it was familiar to the boys, as they had often visited there with their father. When they drew nearer they saw that to-day there were unusual happenings in the city of Chicago. It seemed as though the people of the whole city were gathered on the lake front, but this was not so strange as the fact that the sky was full of aeroplanes attempting to imitate the birds; and these the thousands of people were craning their necks and straining their eyes to see.

A race was evidently in progress, as several aeroplanes were circling a course laid out on the field. 


\section{The Flight B rothers}

Jack's heart beat faster and his eyes gleamed brightly as he grasped the wheel more firmly and said to his brother:

"We'll show 'em, Billy; just wait."

"Go to it, Jack!"

"Hold on to Clutch," said Jack. "Niger can hang on with her claws, I guess."

They joined the aeroplanes and sailed along beside of one, then shot out ahead of it and on to the next, until they had passed them all; then skipped around the course at an unheard-of speed. In a few minutes the other machines had all glided to the ground, while the crowd on the grand stand and in the boxes below yelled and screamed and clapped their hands for the strange new craft.

Jack, urged on by their wild cheering, started to entertain them in earnest. His figure-eights were the most marvelous they had ever seen; his spiral ascents were the fastest and sharpest they had ever witnessed; and his drops the most sensational. He went up into the clouds and coasted down zigzag; and the thrills he gave the people they would not soon forget. And 


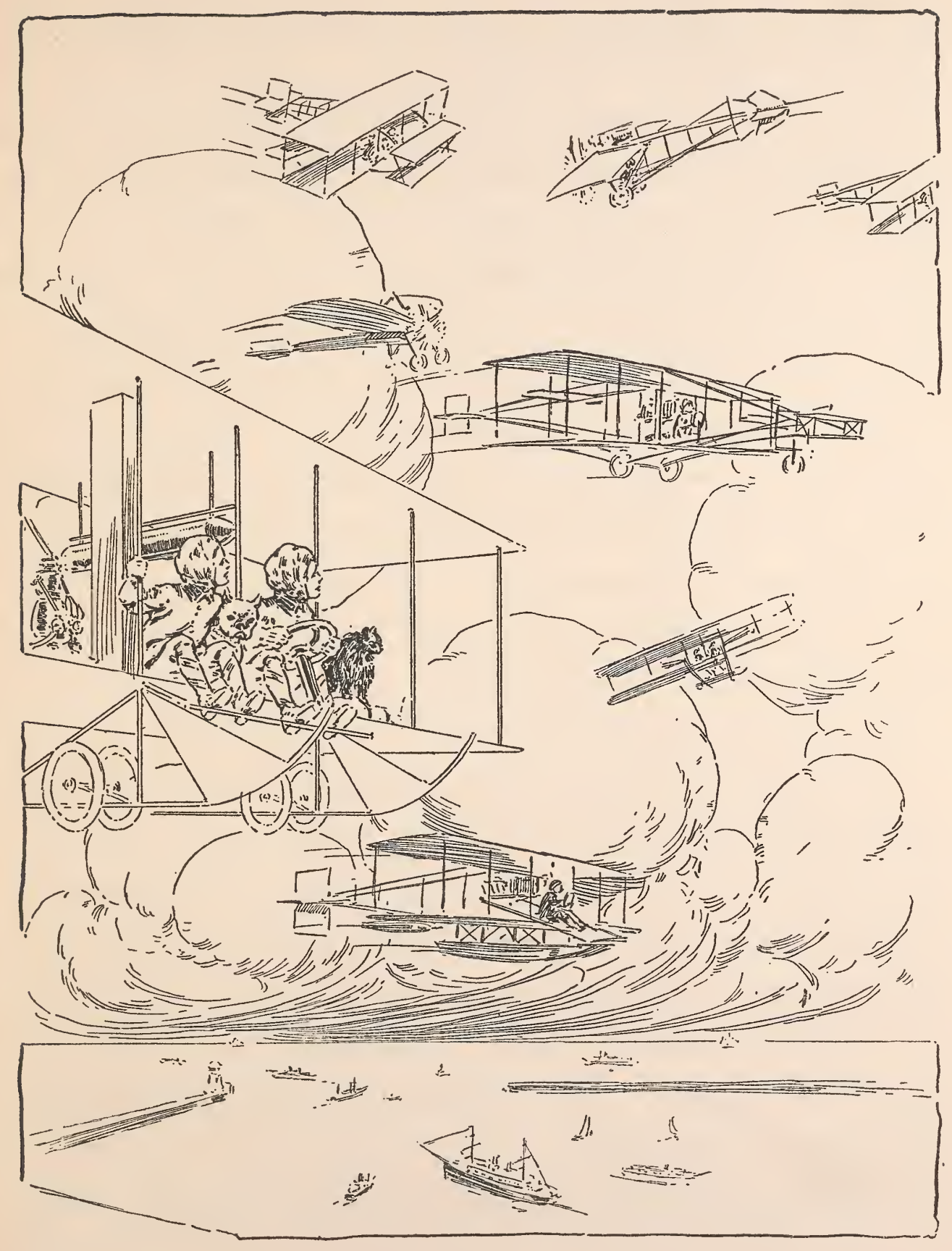




\section{The Flight Brothers}

then the most daring and unheard-of feat ever accomplished without serious results, was performed. When he was making a sharp turn at the extreme end of the field, a strong air current struck the machine when at a slant, causing it to make a complete somersault. For a moment the throng held its breath, thinking an accident had occurred; but when the aeroplane righted itself and continued on its way as much at ease as a bird, the demonstration of enthusiasm knew no bounds; the uproar was deafening.

"Come down! Come down! Who are you?" came from hundreds of megaphones.

"Let's go down," said Billy with a grin.

"Here goes," said Jack, and glided down, landing in front of the judges' stand. With one accord the multitude, the police unable to control it, surged toward the aeroplane and surrounded it, shrieking and yelling and shouting.

"They're only boys!" "Glorious!" "Bully for the Bird Boys!" "Give 'em the purse!" came from hundreds of throats.

This demonstration confused Jack and he wished 


\section{The Flight Brothers}

he had not come down; but Billy enjoyed every bit of it, and the noisier the crowd became the better he liked it. But suddenly there darted toward the aeroplane a little man with a long white beard. It was the Little Brown Man. Throwing a small suit case aboard he jumped in and pushed the boy aside, taking his place at the wheel. At a touch of his finger the aeroplane shot upward, barely missing the heads of the people, and disappeared in the heavens with the speed of a skyrocket.

The Little Brown Man said not a word until they were above the clouds. Then he slackened the speed. Leaning back comfortably, he looked first at Jack and then at Billy, and said with a merry twinkle in his eye:

"I never saw anything like it. All during the time I have had this biplane I never thought of putting it through the circus performance which you did this afternoon. But that is youth and inexperience; and Americans seem to like that sort of thing. But I must admit it looked very pretty from where I stood. I was quite enthusiastic and did some cheering myself. "But," he continued sternly, "you were not following 


\section{The Flight Brothers}

my instructions quite when you landed at that meet." "No," admitted Jack, "we weren't."

"But wasn't it splendid?" demanded Billy, his eyes shining.

"I'll have to agree that it was," replied the Little Brown Man, "but, had you not been in the Perfect Aeroplane, I fear that it would have been-well, something very sad.

"Your brother," he continued, "has become a very accomplished pilot."

In a few minutes he shot downward through the clouds and landed near some large lilac bushes.

"Home!" cried the boys, alighting among the familiar surroundings.

And then the Little Brown Man crawled beneath the machine, and from under the middle of the lower plane unstrapped a long leather box resembling a kodak; opening this, he took out a large roll of films and touched a match to it. For an instant it flared up in a bright green flame which suddenly died out, leaving the roll white.

The boys had curiously watched this proceeding 


\section{The Flight Brothers}

and when the little man unrolled the films they saw before them the completed bird's-eye view pictures of all the places they had passed over.

"One of my inventions," explained the Little Brown Man. "Now I can tell you where you have been. Here you landed in California; you sailed over the Pacific Ocean; next is a terrible scene-Billy and a little girl are surrounded by savages. Where did the little girl come from?"

"From California," said Jack.

"You see," explained the Little Brown Man, "there's hardly a place in the world which is not familiar to me."

"Here," he continued, returning to the pictures, "you pass over a ship; you've come to the city of Honolulu; you make a landing near there; here you leave a throng of

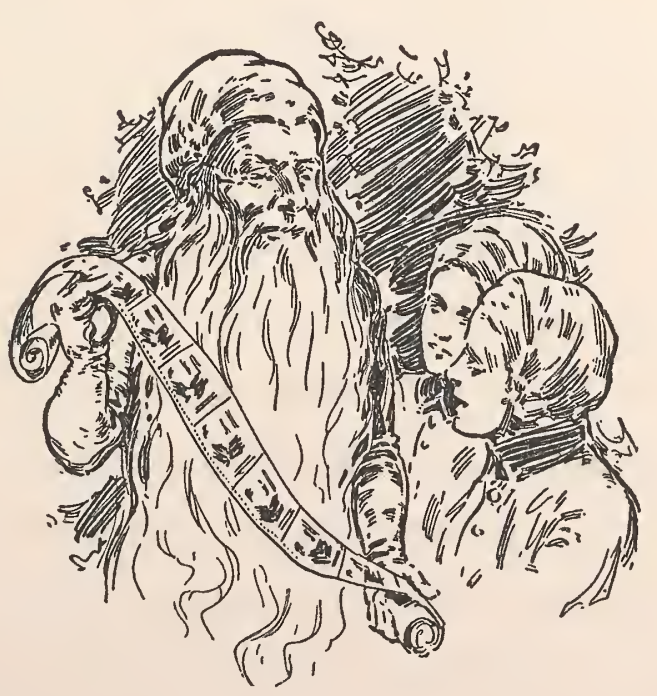




\section{The Flight Brothers}

people and also the little girl. Why, what's this?"

"That must be where the wind turned us over and over," said, Jack.

"That was a typhoon," went on the Little Brown Man. "Next you are sailing above the clouds and landing in India. And-what's this? I have a picture of the tail and hind legs of a tiger; and here he lies below on a rock. Well, well, you must have had some excitement; this is interesting. Next I see a cheering throng-"

"We were giving an exhibition," explained Jack.

"Next you are sailing above the clouds; and here you come to the River Nile, where you flutter around the entrance to the Temple of Rameses II at Abu Simbel in Egypt."

"Was that where the four big statues were?" asked Billy.

"Yes," replied the little man. "And they have been there for thousands of years. And here you cross the great Sahara Desert, stopping once at an oasis. Next I see you in mid-ocean-the Atlantic. And here you pass over New York. See the ships in the harbor! 


\section{The Flight Brothers}

And next you fly down to a wrecked aeroplane. Andwhat's this? A man is hanging to the bottom of your machine-and a dog-this dog," pointing to Clutch, "dangles from the calf of his leg."

Jack related their experience with the aviator and the little man laughed heartily.

"You boys seem to be quite able to take care of yourselves. Some time I shall let you tell me more about your travels, but now I must hurry away." And he jumped aboard the aeroplane.

"That's a mighty fine tiger skin," he said, examining it. "Oh, I see you have 'The Flight Brothers' engraved on the collar. So you were loyal to those names, were you?"

"Every time," said Jack, and Billy added, "You bet.”

"Now, take your menagerie and run home," said the little man. "That's the prettiest cat and the ugliest dog I ever saw. Here's your tiger skin," and he threw it to Jack; then seating himself, he started the motor.

“Thank you very much," said Jack. "You've 


\section{The Flight Brothers}

been so kind and generous in giving us this trip." "Tush, tush!" said the little man. "Tush, tush, nothing," cried Billy. "You bet you have and we won't forget it."

"That's all right, boys. Good-bye. I'll drop out of the sky and see you again one of these days."

"Make it soon," called Jack as the aeroplane rose in the air, then remarked to his brother as they watched the Little Brown Man fly away:

"Well, I guess this is the end of the Flight Brothers." 




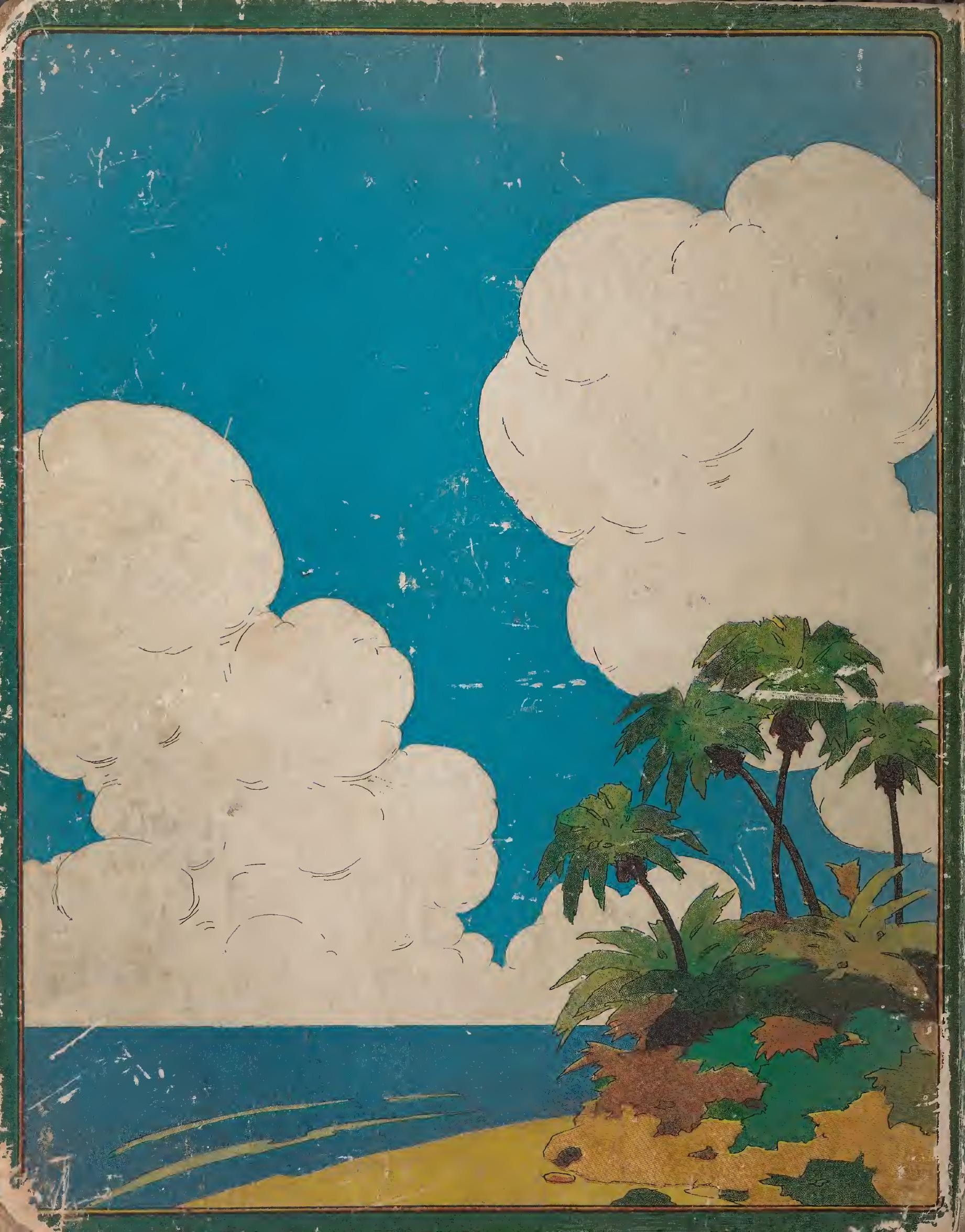

